\title{
Process simulation and gate-to-gate life cycle assessment of hydrometallurgical refractory gold concentrate processing
}

\author{
Heini Elomaa ${ }^{1} \cdot$ Pia Sinisalo $^{2} \cdot$ Lotta Rintala $^{3} \cdot$ Jari Aromaa $^{1} \cdot$ Mari Lundström ${ }^{1}$
}

Received: 9 May 2019 / Accepted: 12 December 2019 / Published online: 26 December 2020

(C) The Author(s) 2019

\begin{abstract}
Purpose Currently, almost all cyanide-free gold leaching processes are still in the development stage. Proactively investigating their environmental impacts prior to commercialization is of utmost importance. In this study, a detailed refractory gold concentrate process simulation with mass and energy balance was built for state-of-the-art technology with (i) pressure oxidation followed by cyanidation and, compared to alternative cyanide-free technology, with (ii) pressure oxidation followed by halogen leaching. Subsequently, the simulated mass balance was used as life cycle inventory data in order to evaluate the environmental impacts of the predominant cyanidation process and a cyanide-free alternative.

Methods The environmental indicators for each scenario are based on the mass balance produced with HSC Sim steady-state simulation. The simulated mass balances were evaluated to identify the challenges in used technologies. The HSC Sim software is compatible with the GaBi LCA software, where LCI data from HSC-Sim is directly exported to. The simulation produces a consistent life cycle inventory (LCI). In GaBi LCA software, the environmental indicators of global warming potential (GWP), acidification potential (AP), terrestrial eutrophication potential (EP), and water depletion (Water) are estimated.

Results and discussion The life cycle assessment revealed that the GWP for cyanidation was $10.1 \mathrm{t} \mathrm{CO}_{2}$-e/kg Au, whereas the halogen process indicated a slightly higher GWP of $12.6 \mathrm{t} \mathrm{CO}_{2}-\mathrm{e} / \mathrm{kg} \mathrm{Au}$. The difference is partially explained by the fact that the footprint is calculated against produced units of $\mathrm{Au}$; total recovery by the halogen leaching route for gold was only $87.3 \%$, whereas the cyanidation route could extract as much as $98.5 \%$ of gold. The addition of a second gold recovery unit to extract gold also from the washing water in the halogen process increased gold recovery up to $98.5 \%$, decreasing the GWP of the halogen process to $11.5 \mathrm{t} \mathrm{CO}_{2}-\mathrm{e} / \mathrm{kg} \mathrm{Au}$. However, both evaluated halogen processing scenarios indicated a slightly higher global warming potential when compared to the dominating cyanidation technology.

Conclusions The estimated environmental impacts predict that the development-stage cyanide-free process still has some challenges compared to cyanidation; as in the investigated scenarios, the environmental impacts were generally higher for halogen leaching. Further process improvements, for example in the form of decreased moisture in the feed for halide leaching, and the adaptation of in situ gold recovery practices in chloride leaching may give the cyanide-free processing options a competitive edge.
\end{abstract}

Keywords Cyanide-free $\cdot$ Gold leaching $\cdot$ Gate to gate $\cdot$ Halides $\cdot$ Pressure oxidation $\cdot$ Simulation

Responsible editor: Andrea J Russell-Vaccari

Electronic supplementary material The online version of this article (https://doi.org/10.1007/s11367-019-01723-6) contains supplementary material, which is available to authorized users.

Mari Lundström mari.lundstrom@aalto.fi

1 School of Chemical Engineering, Department of Chemical and Metallurgical Engineering, Aalto University, Vuorimiehentie 2, AALTO, P.O. Box 16200, FI-00076 Espoo, Finland
2 Fortum, Recycling and Waste, Kirrinsannantie 6, FI-28880 Pori, Finland

3 VTT Technical Research Centre of Finland Ltd, Solutions for Natural Resources and Environment, Vuorimiehentie 2, VTT, P.O. Box 1000, FI-02044 Espoo, Finland 


\section{Introduction}

Cyanidation of gold has dominated the gold leaching industry since the 1900s as a generally effective and fairly low-cost process. However, direct cyanidation of refractory ores, lowgrade ores, and certain complex ore types suffer from low gold recoveries $(<80 \%)$, high cyanide consumption, or both. In addition, the toxicity of cyanide and related strict environmental legislation control the use of cyanide and operations in the gold plant (Fleming 1992). These factors motivate not only the development of cyanide-free gold processes but also their early-stage evaluation of process mass and energy balances as well as environmental impacts.

In the recent decades, 27 different lixiviants have been investigated as possible replacements to cyanidation, most of them based on thiosulfate, thiourea, and halide systems (Aylmore 2016). More recently, cyanide-free processes using chloride solutions at ambient pressure and at low temperature have been researched and tested on pilot scale (Ishiguro et al. 2008; Haavanlammi et al. 2010; Harris and White 2014). In halogen/ halide processes, the oxidant can be chlorine (Rose 1898), hypohalides (Yen et al. 1990), a cupric/cuprous redox couple (Lundström et al. 2014; Lundström et al. 2015; Lampinen et al. 2017), or a ferric/ferrous redox couple (Seisko et al. 2018) and the complexing agent is chloride. Many literature reviews have explored the chemistry of these alternative processes (Nicol et al. 1987; Tran et al. 2001; Hilson and Monhemius 2006; Aylmore 2016), and it is generally acknowledged that the kinetics in halide solutions are faster compared to cyanidation (Jeffrey et al. 2001). Gold leaching by hypochlorite has been studied by Baghalha (2007) and Yen et al. (1990), who suggest that an oxidative pretreatment should be adopted when processing refractory ore (Yen et al. 1990). Gold leaching in hypohalide media is highly dependent on the acidity and generates chlorine gas (Lalancette 2009; Lalancette et al. 2015a). A halogen process utilizing this phenomena has been researched by Lemieux et al. (2014) and De Michelis et al. (2013). Both these studies show that the hypohalide system can provide efficient gold leaching both on laboratory and demonstration scale.

An increasing amount of global gold production derives from refractory-type materials. These materials have high concentrations of sulfide minerals that encapsulate the gold, such as pyrite and arsenopyrite, and preg-robbing material such as carbonaceous minerals. They require pre-treatment methods such as roasting, pressure oxidation, or bioleaching (Haque 1987; Fleming 1992; Marsden and House 2006). Moreover, pre-oxidation of sulfide minerals generates sulfuric acid and ferric ions that require neutralization prior to cyanidation, which can be avoided when using alternative acidic cyanidefree leaching (Fleming 1992).

Considering the challenges of refractory gold ore processing by cyanidation and the need for a cyanide-free option, it is essential to evaluate the process performance and environmental impacts of cyanide-free development-stage processes prior to commercialization. The HSC Chemistry Sim module (Outotec 2018) creates metallurgical steady state simulations and mass balances, which can be utilized as life cycle inventory in GaBi LCA software (thinkstep 2019). Previously, simulation combined with life cycle assessment has been used by several researchers to evaluate different metallurgical processes (Kotiranta et al. 2015; Reuter et al. 2015; Ghodrat et al. 2017; Llamas et al. 2019). However, the compatibility of HSC Sim and GaBi has not yet been adapted to the hydrometallurgical processing of gold, in particular to the cyanide-free process options. The objective of this paper is to present an early-stage evaluation of the environmental impacts of the gold halogen process and to compare that to the state-ofart cyanidation. GaBi LCA software was used to estimate the global warming potential (GWP), acidification potential (AP), terrestrial eutrophication potential (EP), and water depletion (Water) of the process.

\section{SCE1 and SCE2 processes}

In the state-of-art industry, refractory gold ore is pre-treated prior to cyanidation to liberate the gold (La Brooy et al. 1994; Fraser et al. 1991). Known pretreatment methods are roasting (Hammerschmidt et al. 2016), pressure oxidation, (POX) (Mason et al. 1985; Thomas et al. 1990; Pangum and Browner 1996; Marchbank et al. 1996) and bioleaching (Iglesias and Carranza 1994; Brierley and Brierley 2001). Figure 1 presents the scenarios investigated in this study. The chosen processing route was POX of refractory concentrate and subsequent cyanidation (SCE1). This is compared to the developmentstage process of POX followed by halogen leaching (SCE2). The resulting gold can then be processed through smelting to produce gold bullion. The following sections describe briefly the chemistry of the unit processes, i.e., POX, cyanidation, and halogen leaching used in SCE1 and SCE2. A more detailed description is presented in the Electronic Supplementary Material (ESM) in sections S1.1, S1.2 and S1.3.

Theoretical gold recoveries and process arrangements based on the literature were used in this study. It must be noted that the results are indicative, as the material-specific gold recoveries and the detailed method of gold recovery require tailored experimental test work for each raw material separately. The raw material used as the gold concentrate in the current study was mainly similar to that investigated by Fleming et al. (2008); therefore, similar conditions were used in the POX simulation, indicating full liberation of gold during the process. There is a significant amount of published information regarding the cyanidation of gold, whereas halogen leaching has not been reported as comprehensively. The flowsheet built for halogen leaching is based on literature data and includes 
Fig. 1 The studied scenarios SCE1 consisting of POX and cyanidation (state-of-art) and SCE2 consisting of POX and halogen leaching

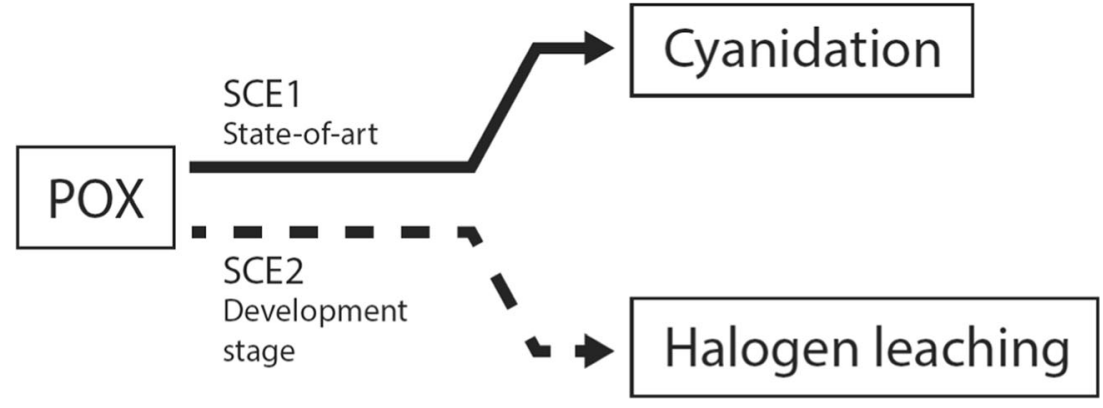

some modifications required for industrial scale, adopted from known technologies.

\subsection{Pressure oxidation}

Generally, POX targets pyrite and arsenopyrite oxidation for the complete liberation of gold (Eqs. 1 and 2). The POX is performed at a temperature between 180 and $225^{\circ} \mathrm{C}$, a total pressure of between 1900 and $3380 \mathrm{kPa}(275$ and $490 \mathrm{psia})$, and an oxygen partial pressure of at least $173 \mathrm{kPa}$ (25 psia) for a period of at least $60 \mathrm{~min}$ (Thomas et al. 1990). Typically, the oxidation degree of sulfide sulfur aimed for is in the range of 50 to $95 \%$. This is affected by the amount of sulfide sulfur, the nature of the sulfides in the ore, and the distribution of gold.

$2 \mathrm{FeS}_{2}+7.5 \mathrm{O}_{2}+4 \mathrm{H}_{2} \mathrm{O} \rightarrow \mathrm{Fe}_{2} \mathrm{O}_{3}+4 \mathrm{H}_{2} \mathrm{SO}_{4}$

$2 \mathrm{FeAsS}+7 \mathrm{O}_{2}+2 \mathrm{H}_{2} \mathrm{O} \rightarrow 2 \mathrm{FeAsO}_{4}+2 \mathrm{H}_{2} \mathrm{SO}_{2}$

During process, it has been suggested that iron precipitates as hematite through formation of iron sulfate, which also can form jarosite precipitate. Arsenic forms a stable precipitate with iron as ferric arsenate (Haque 1987; Fleming 1992). Sulfuric acid is generated in situ in the autoclave under operating conditions, Eqs. 1 and 2, see ESM S1.1 for the reaction mechanisms. It is beneficial to maintain excess sulfuric acid in the autoclave, in order to promote oxidation and prevent pregrobbing phenomena (Marchbank et al. 1996; Fleming et al. 2008).

\subsection{Cyanidation}

Currently, cyanidation is the predominant process for gold leaching. Cyanide is introduced into the system mainly as sodium, calcium, or potassium cyanide (Marsden and House 2006). In aqueous alkaline solution, gold oxidizes and dissolves in $\mathrm{Au}(\mathrm{I})$ form and complexes with $\mathrm{CN}^{-}$to form an $\mathrm{Au}(\mathrm{CN})_{2}{ }^{-}$complex. The stability of dicyanoaurate ion $\left(\log \beta_{2}=39.3, \beta_{2}=2 \times 10^{38}\right)$ is significant compared to other complexes. It is known that high gold recovery can be achieved with cyanidation. Recoveries of over $90 \%$ are reported in the literature, required for economically feasible processes. However, with direct cyanidation, refractory-type ores are defined to reach less than $80 \%$ recovery. The overall dissolution reaction of gold in aerated, alkaline cyanide solutions proposed by Elsner (1846) is shown in Eq. 3:

$4 \mathrm{Au}+8 \mathrm{CN}^{-}+\mathrm{O}_{2}+2 \mathrm{H}_{2} \mathrm{O}=4 \mathrm{Au}(\mathrm{CN})_{2}{ }^{-}+4 \mathrm{OH}^{-}$

One of the prevailing challenges in cyanidation is related to impurities such as copper and reactive sulfides such as pyrrhotite. Copper forms stable cyanocomplexes, which increase the consumption of sodium cyanide in the process (Marsden and House 2006). Pyrrhotite and other sulfides can lead to high oxygen requirements due to the oxidation reactions of $\mathrm{Fe}^{2+}$ to $\mathrm{Fe}^{3+}$ and sulfide to sulfate (La Brooy et al. 1994). In addition, other impurities, for instance $\mathrm{As}, \mathrm{Ni}, \mathrm{Sb}$, and $\mathrm{Zn}$, can increase the consumption of either cyanide or oxygen, hindering the recovery of gold (Aylmore and Muir 2001). Furthermore, carbonaceous and clay-type material in the ore enhance the preg-robbing phenomena by absorbing $\mathrm{Au}$ cyanoanions and preventing the dissolution of $\mathrm{Au}$ (La Brooy et al. 1994). The possible cyanide-consuming dissolution reactions of sulfide minerals are suggested in Eqs. 4-6 (Zhang et al. 1997; Kianinia et al. 2018):

$$
\begin{aligned}
\mathrm{FeS}_{2}(\mathrm{~s})+6 \mathrm{CN}^{-}=\mathrm{Fe}(\mathrm{CN})_{6}{ }^{4-}+\mathrm{S}_{2}{ }^{2-} & \\
\mathrm{CuFeS}_{2}(\mathrm{~s})+10 \mathrm{CN}^{-}= & \mathrm{Cu}(\mathrm{CN})_{4}{ }^{3-}+\mathrm{Fe}(\mathrm{CN})_{6}{ }^{4-} \\
& +2 \mathrm{~S}^{2-}
\end{aligned}
$$

$\mathrm{FeS}(\mathrm{s})+6 \mathrm{CN}^{-}=\mathrm{Fe}(\mathrm{CN})_{6}{ }^{4-}+\mathrm{S}^{2-}$

Due to the oxidizing conditions in cyanidation, the forming $\mathrm{S}^{2-}$ can oxidize further to sulfate (Zhang et al. 1997). These minerals should be transformed to another form prior to cyanidation, for example hematite, which is insoluble in cyanidation (Hayes 1985). Carbon in leach (CIL) has been shown to provide higher recovery of gold from refractorytype ores (Fleming 1992). Gold is stripped from the activated 
carbon in the elution process to produce a smaller volume of gold-rich solution from which the gold can be recovered through electrowinning. The gold cathodes are subjected to smelting and cast into gold bullion. In order to decrease the environmental risks related to $\mathrm{CN}$, the cyanide solutions are detoxified. The most common oxidation process for $\mathrm{CN}$ is the sulfur dioxide assisted process, where $\mathrm{Na}_{2} \mathrm{SO}_{3}$ or $\mathrm{Na}_{\mathrm{s}} \mathrm{S}_{2} \mathrm{O}_{5}$ is used as a source of sulfur dioxide. A mixture of sulfur dioxide and air oxidizes the free cyanide in solution according to Eq. 7 into a form in which it can be disposed of (Marsden and House 2006):

$$
\mathrm{CN}^{-}+\mathrm{SO}_{2}+\mathrm{O}_{2}+\mathrm{H}_{2} \mathrm{O} \leftrightarrow \mathrm{OCN}^{-}+\mathrm{H}_{2} \mathrm{SO}_{4}
$$

\subsection{Halogen leaching}

Chlorine has been known to leach gold from ores and concentrates since the 1800s (Rose 1898). A process using halogens recycled as hypochlorites for gold leaching from refractory gold ores has been patented recently (Lalancette et al. 2015a). This process was chosen for comparison as it is one of the closest to commercialization among the cyanide-free options. In the process, precious metals are dissolved by the action of halogens or halogen derivatives and recovered from the pregnant solution, while facilitating the recycling of halogens from the resulting barren solution. The redox potential of the solution has to be maintained at appropriate values, in the range of 0.7 to about $1.2 \mathrm{~V}$ vs. $\mathrm{Ag} / \mathrm{AgCl}$ (Lalancette et al. $2015 \mathrm{a}$ ), and more specifically $0.8 \mathrm{~V}$ vs. $\mathrm{Ag} / \mathrm{AgCl}$ in order to dissolve gold (Marsden and House 2006). The recovery of gold can be done with activated carbon. However, in the case of halogen leaching and particularly with bromine, the halogens have a tendency to form stable halogenated compounds with carbon. This disturbs the recycling of the halogens and creates halogenated carbon disposal problem. Consequently, an alternative recovery method called silica adsorption has been proposed (Lalancette et al. 2015a). The gold silica/ precipitate product can be directly subjected to a pyrometallurgical process to produce gold bullion. In the halogen leaching, halogens such as chlorine and bromine are used as free halogens for the oxidation of precious metals and are recycled by electrolysis of the barren solution in the form of hypohalides. (Lalancette et al. 2015a) According to Lemieux et al. (2014), there is interaction with elemental $\mathrm{Cl}_{2}$, which oxidizes the dissolved $\mathrm{Br}^{-}$ions to $\mathrm{Br}_{2}$ (Eq. 8), and the corresponding formation of $\mathrm{Cl}^{-}$. Therefore, $\mathrm{Cl}_{2}$ will generate $\mathrm{Br}_{2}$ for efficient gold oxidation (Eq. 9). The product, $\mathrm{AuBr}_{3}$, will be further transformed to $\mathrm{AuCl}_{3}$ (Eq. 10).

$2 \mathrm{NaBr}+\mathrm{Cl}_{2}=\mathrm{Br}_{2}+2 \mathrm{NaCl}$

$2 \mathrm{Au}+3 \mathrm{Br}_{2}=2 \mathrm{AuBr}_{3}$

$2 \mathrm{AuBr}_{3}+3 \mathrm{Cl}_{2}=2 \mathrm{AuCl}_{3}+3 \mathrm{Br}_{2}$
The $\mathrm{Cl}$ and $\mathrm{Br}$ gases will react with water to form hypohalides, as shown in Eqs. 11 and 12, whereas the liberation of free halogens follows Eq. 13. The recycling of halogens is based on the electrolysis in the simulated process, and the excess halogens are then scrubbed with sodium hydroxide. A more detailed process description is found in the ESM section S1.3.

$$
\begin{aligned}
& \mathrm{Cl}_{2}+\mathrm{H}_{2} \mathrm{O}=\mathrm{HClO}+\mathrm{HCl} \\
& \mathrm{Br}_{2}+\mathrm{H}_{2} \mathrm{O}=\mathrm{HBrO}+\mathrm{HBr} \\
& 2 \mathrm{OCl}^{-} / 2 \mathrm{OBr}^{-}+4 \mathrm{H}^{+} \rightarrow \mathrm{Cl}_{2} / \mathrm{Br}_{2}+2 \mathrm{H}_{2} \mathrm{O}
\end{aligned}
$$

\section{Process simulation}

The HSC Sim module was used to build the flowsheet simulations. Each simulation is based on the modeling of selected and defined unit processes and their continuum with the known and/or published chemistry. The user defines the input(s) and its/their mineralogical/chemical composition (such as Table 1) as well as possible chemical reactions and their progress. This allows the steady-state simulation of the output(s) and energy balance of the unit. The output of the first unit is the feed for the next unit(s) or product or bleeds out of the process, and thus, the entire flowsheet modeling allows the evaluation of mass and energy balances, losses, and emissions in the process accurately. The parameters of each unit are based on published literature or estimates values made by a person skilled in industrial

Table 1 The balanced mineralogy of the gold concentrate material used in the simulation of SCE1 and SCE2 (Jaatinen 2011)

\begin{tabular}{lcc}
\hline Mineral & Value & Unit \\
\hline $\mathrm{Au}$ & 38.7 & $\mathrm{ppm}$ \\
$\mathrm{Ag}$ & 33 & $\mathrm{ppm}$ \\
$\mathrm{FeAsS}$ & 13.8 & $\%$ \\
$\mathrm{Cu}_{10} \mathrm{Fe}_{2} \mathrm{Sb}_{4} \mathrm{~S}_{13}$ & 0.34 & $\%$ \\
$\mathrm{C}$ & 1.95 & $\%$ \\
$\mathrm{FeS}_{2}$ & 32.1 & $\%$ \\
$\mathrm{Fe}_{2} \mathrm{O}_{3}$ & 2.27 & $\%$ \\
$\mathrm{NiSb}$ & 0.22 & $\%$ \\
$\mathrm{PbS}$ & 0.06 & $\%$ \\
$\mathrm{Sb}_{2} \mathrm{~S}_{3}$ & 0.19 & $\%$ \\
$\mathrm{FeO} \mathrm{TiO}_{2}$ & 1.71 & $\%$ \\
$\mathrm{NaAlSi}_{3} \mathrm{O}_{8}$ & 4.82 & $\%$ \\
$\mathrm{KAl}_{2}\left(\mathrm{Si}_{3} \mathrm{Al}\right) \mathrm{O}_{10}(\mathrm{OH})_{2}$ & 15.22 & $\%$ \\
$\mathrm{CaCO}_{3}$ & 7.01 & $\%$ \\
$\mathrm{MgCO}_{3}$ & 5.31 & $\%$ \\
$\mathrm{SiO}_{2}$ & 15.02 & $\%$ \\
$\mathrm{Sum}$ & 100 &
\end{tabular}


process design. In the current work, three models were built: POX, cyanidation, and halogen leaching. POX is the pretreatment step used prior to both gold cyanidation and halogen leaching. Therefore, in the current work, POX is an identical step followed by either cyanidation or halogen leaching.

\subsection{Gold raw material used in simulation}

The raw material used in the simulation is refractory gold concentrate, originating from a Finnish gold deposit (Jaatinen 2011). Based on the mineralogical and chemical analysis, a balanced composition of the material was calculated (Table 1). In the simulation, the dry concentrate feed to the POX is $40.2 \mathrm{t} / \mathrm{h}$, corresponding to an annual production of approximately $10,000 \mathrm{~kg}$ of gold.

\subsection{Pressure oxidation simulation flow sheet}

The process flowsheet of POX is presented in Fig. 2 and the parameters for each unit in POX simulation in Table 2.
In the simulation, the refractory gold concentrate $(40.2 \mathrm{t} / \mathrm{h})$ is first subjected to pre-acidulation. The input material is flotation concentrate; thus, some water (23\% of the feed) enters the process with it. The pre-acidulation unit introduces a significant amount of freshwater into the process in the current simulation. Slurry, with an optimal solids concentration of $12 \%$ (Conway and Gale 1990) for 30\% sulfide content, is pre-heated according to the patent of Thomas et al. (1990), utilizing the excess heat of flash tanks. However, direct steam as such would challenge the water balance of the autoclave, which motivates the utilization of a mixer to provide $100{ }^{\circ} \mathrm{C}$ steam for preheating. It is likely, that the exothermic reactions in POX and the mineralogy of the studied material may enable the autoclave to maintain the required temperature without preheating. POX is conducted at $190{ }^{\circ} \mathrm{C}$ with $12 \%$ slurry, the parameters being similar to those published by Fleming et al. (2008), for a very similar raw material. Flash tanks release 29.2 and $32.6 \mathrm{t} / \mathrm{h}$ of steam for heat utilization and $384 \mathrm{t} / \mathrm{h}$ of slurry to the thickener. The underflow (UF,

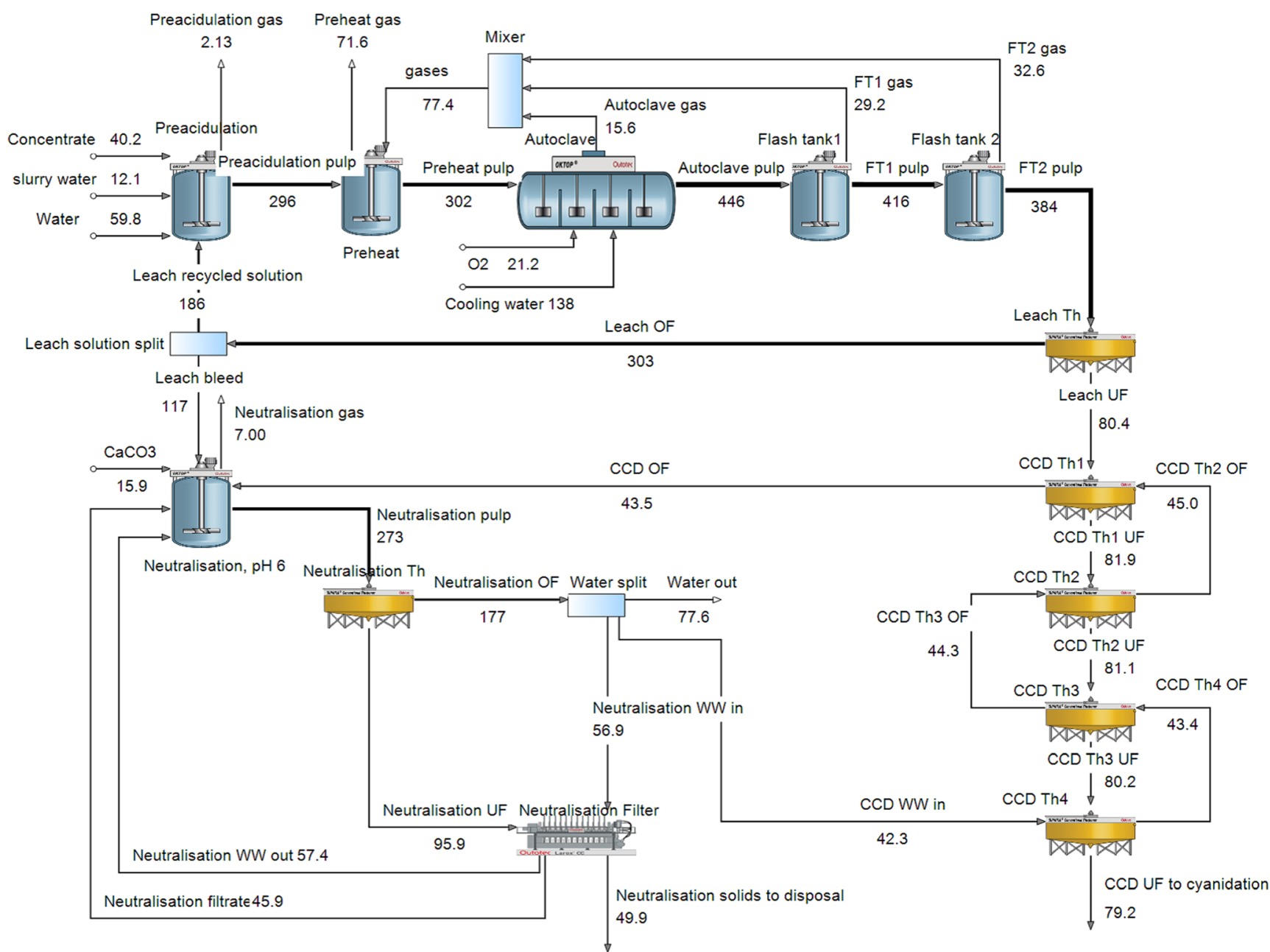

Fig. 2 The flowsheet of POX simulation for refractory gold concentrate, showing mass balance ( $\mathrm{t} / \mathrm{h})$ for each flow with ca. $10,000 \mathrm{~kg} / \mathrm{a}$ gold production 
Table 2 The parameters used in the simulation of the $\mathrm{POX}$ process

\begin{tabular}{|c|c|c|c|c|}
\hline Unit process & Parameter & Value & Control unit & Reference \\
\hline \multicolumn{5}{|c|}{ Controlled parameters } \\
\hline Preheat & Slurry concentration & $12 \%$ & Pre-acidulation & $\begin{array}{l}\text { Estimation based on Conway } \\
\text { and Gale (1990) }\end{array}$ \\
\hline Autoclave & $\begin{array}{l}\text { Oxygen partial } \\
\text { pressure }\end{array}$ & $100 \mathrm{psi}$ & Autoclave & Fleming et al. (2008) \\
\hline Autoclave & $\mathrm{Fe}^{3+}$ concentration & $10 \mathrm{~g} / \mathrm{L}$ & Autoclave & Estimation \\
\hline Autoclave & As concentration & $1 \mathrm{~g} / \mathrm{L}$ & Autoclave & Estimation \\
\hline Autoclave & $\begin{array}{l}\text { Free acid } \\
\quad \text { concentration }\end{array}$ & $\begin{array}{r}85 \mathrm{~g} / \mathrm{L} \text { after } \\
\text { autoclave }\end{array}$ & $\begin{array}{l}\text { Leach solution } \\
\text { split }\end{array}$ & Fleming et al. (2008) \\
\hline \multicolumn{5}{|l|}{ Other parameters } \\
\hline Autoclave & Temperature & $190^{\circ} \mathrm{C}$ & & Fleming et al. (2008) \\
\hline Autoclave & $\begin{array}{l}\text { Sulfide mineral } \\
\text { oxidation degree }\end{array}$ & $99.8 \%$ & & Fleming et al. (2008) \\
\hline CCD circuit & $\begin{array}{l}\text { solid conc. in } \\
\text { underflow }\end{array}$ & $40 \%$ & & HSC Thickener standard \\
\hline Filtration & Filtration efficiency & $96 \%$ & & HSC Filter standard \\
\hline Filtration & $\begin{array}{l}\text { Filtration cake } \\
\text { moisture }\end{array}$ & $25 \%$ & & HSC Filter standard \\
\hline Filtration & $\begin{array}{l}\text { Washing water } \\
\text { amount }\end{array}$ & $\begin{array}{l}1.5 \mathrm{~m}^{3} / \mathrm{t} \text { of } \\
\text { solids }\end{array}$ & & HSC Filter standard \\
\hline Neutralization & $\mathrm{pH}$ & 6 & & Estimation \\
\hline
\end{tabular}

$80.4 \mathrm{t} / \mathrm{h}$ ) is subjected to counter-current decantation (CCD) for washing of solids, whereas the overflow (OF) is partially $(186 \mathrm{t} / \mathrm{h})$ circulated back to pre-acidulation. The rest of the OF solution $(117 \mathrm{t} / \mathrm{h})$ is routed to neutralization using $\mathrm{CaCO}_{3}(15.9 \mathrm{t} / \mathrm{h})$. The neutralized solution is then used in the washing of neutralization residue and leach residue in the CCD circuit. The excess water $(77.6 \mathrm{t} / \mathrm{h})$ must be bled out of the process. This water is neutralized at $\mathrm{pH} 6$ but contains sulfates $(17.6 \mathrm{~g} / \mathrm{L})$. It can be used in subsequent unit processes or disposed of after water purification, as one recommended sulfate limit being $1000 \mathrm{mg} /$ $\mathrm{L}$ in mine waters in Europe (Bowell 2004). The process water removed in the neutralization, as well as the evaporated water of flash tanks, could be partially reused to replace the amount of used fresh water in pre-acidulation. However, the current model is based on the use of fresh water in the pre-acidulation.

The main principles and observations of the simulated POX process are described in the following sections.

\subsubsection{Sulfuric acid consumption}

Several patents suggest sulfur acid concentration of preferably less than $25 \mathrm{~g} / \mathrm{L}$ should be maintained by sulfur oxidation in POX (Thomas et al. 1990; Marchbank et al. 1996). However, the results of the current study suggest that up to as much as $85 \mathrm{~g} / \mathrm{L}$ of sulfuric acid can be maintained without addition of sulfuric acid chemical. The current simulation is operated at high acidity as it has been suggested to prevent preg-robbing and improve gold recovery by $2-3 \%$. In addition, this may allow more consistent and stable metallurgical performance for highly refractory gold concentrate (Fleming et al. 2008). The leach solution is reused in the pre-acidulation unit.

\subsubsection{Neutralization}

The simulation reveals that the calcium carbonate consumption in solution neutralization is $398 \mathrm{~kg} / \mathrm{t}$ concentrate, based on stoichiometric reaction. The neutralization products are jarosites (Pangum and Browner 1996) and oxides and hydroxides such as $\mathrm{FeAsO}_{4}, \mathrm{Cu}(\mathrm{OH})_{2}$, $\mathrm{CaSO}_{4} \cdot 2 \mathrm{H}_{2} \mathrm{O}$, and $\mathrm{Al}(\mathrm{OH})_{3}$. In addition, the simulation shows that some of the dissolved arsenic $\left(1 \mathrm{~g} / \mathrm{L}, \mathrm{AsO}_{4}{ }^{-}\right)$ will end up in the neutralization stage and may consequently re-dissolve from the solid tailings. For this reason, the resulting tailings are characterized as hazardous substances and must be discharged into specific ponds. Contemporary practices for this kind of tailing materials are paste thickening and use as a backfill in underground mines, for example (Pöyry 2015).

\subsubsection{Off gases}

The results confirm that carbon dioxide is produced during POX process. In the simulations, these gases are not treated and are released into the environment as such. The effect of the $\mathrm{CO}_{2}$ gases produced is seen in the life cycle assessment section. 


\subsubsection{Treated concentrate}

POX produces an oxidized concentrate, subjected to a gold leaching process after CCD washing, in the form of thickener underflow. The solid concentration of the slurry is $36 \%$, it is acidic, and it contains $28.6 \mathrm{t} / \mathrm{h}$ of undissolved silicate minerals. Sulfide mineral dissolution in POX has liberated the gold, whose concentration has increased to $54.3 \mathrm{ppm}$ in underflow slurry.

\subsection{State-of-art cyanidation flow sheet}

In the SCE 1 process, cyanidation is conducted for POXtreated gold concentrate. The unit processes are modeled as one unit; however, in a real process, the carbon-in-leach/CIL circuit consists of multiple reactors. The oxidized concentrate, i.e., the UF of CCD circuit $(79.2 \mathrm{t} / \mathrm{h})$, is subjected to $\mathrm{pH}$ control by $\mathrm{Ca}(\mathrm{OH})_{2}(0.88 \mathrm{t} / \mathrm{h})$. Due to the risk of the formation of lethal hydrogen cyanide gas, maintaining a high $\mathrm{pH}$ is crucial for safe plant operation. 79.2 $\mathrm{t} / \mathrm{h}$ of slurry is subjected for CIL, where gold dissolves and adsorbs on carbon, at $\mathrm{pH} 10$ and keeping the $\mathrm{NaCN}$ level at $0.5 \mathrm{~g} / \mathrm{L}$. After leaching, the bleed solution is routed to the cyanide destruction unit, which consumes air $(65 \mathrm{~kg} / \mathrm{h}), \mathrm{Na}_{2} \mathrm{SO}_{3}(83 \mathrm{~kg} / \mathrm{h}$, calculated from the composition of the flow) and $\mathrm{Ca}(\mathrm{OH})_{2}(49 \mathrm{~kg} / \mathrm{h})$, after which the tailings can be discharged into ponds.

In a real process, the loaded carbon is gathered in hoppers prior to proceeding to the next unit process in order to adjust the batch sizes. In the steady-state simulation, these hoppers were excluded. However, the recovery process was simulated as a 1-t batch, for equipment sizing purposes.

Of loaded carbon, $1 \mathrm{t} / \mathrm{h}$ is treated in the recovery process, where the carbon is first washed with $3 \% \mathrm{HCl}$ solution to remove impurities. In the elution column, gold is stripped from the carbon by soaking in $35 \mathrm{~g} / \mathrm{L} \mathrm{NaCN}(0.46 \mathrm{t} / \mathrm{h})$ and $12.5 \mathrm{~g} / \mathrm{L} \mathrm{NaOH}(0.17 \mathrm{t} / \mathrm{h})$ solution, and then washed with water $(12.2 \mathrm{t} / \mathrm{h})$, which is five times the carbon bed volume. Subsequently, gold is electrowon from the solution and a similar detoxification is used for the cyanide solution, consuming $1.3 \mathrm{t} / \mathrm{h}$ of $\mathrm{Na}_{2} \mathrm{SO}_{3}, 1.15 \mathrm{t} / \mathrm{h}$ of air and $0.79 \mathrm{t} / \mathrm{h}$ of $\mathrm{Ca}(\mathrm{OH})_{2}$.

The results of the mass balance for each unit process flowsheet of gold leaching by cyanidation are shown in Figs. 3 and 4. The loaded carbon output of leaching was increased to and input of $1.08 \mathrm{t} / \mathrm{h}$ in the recovery simulation.

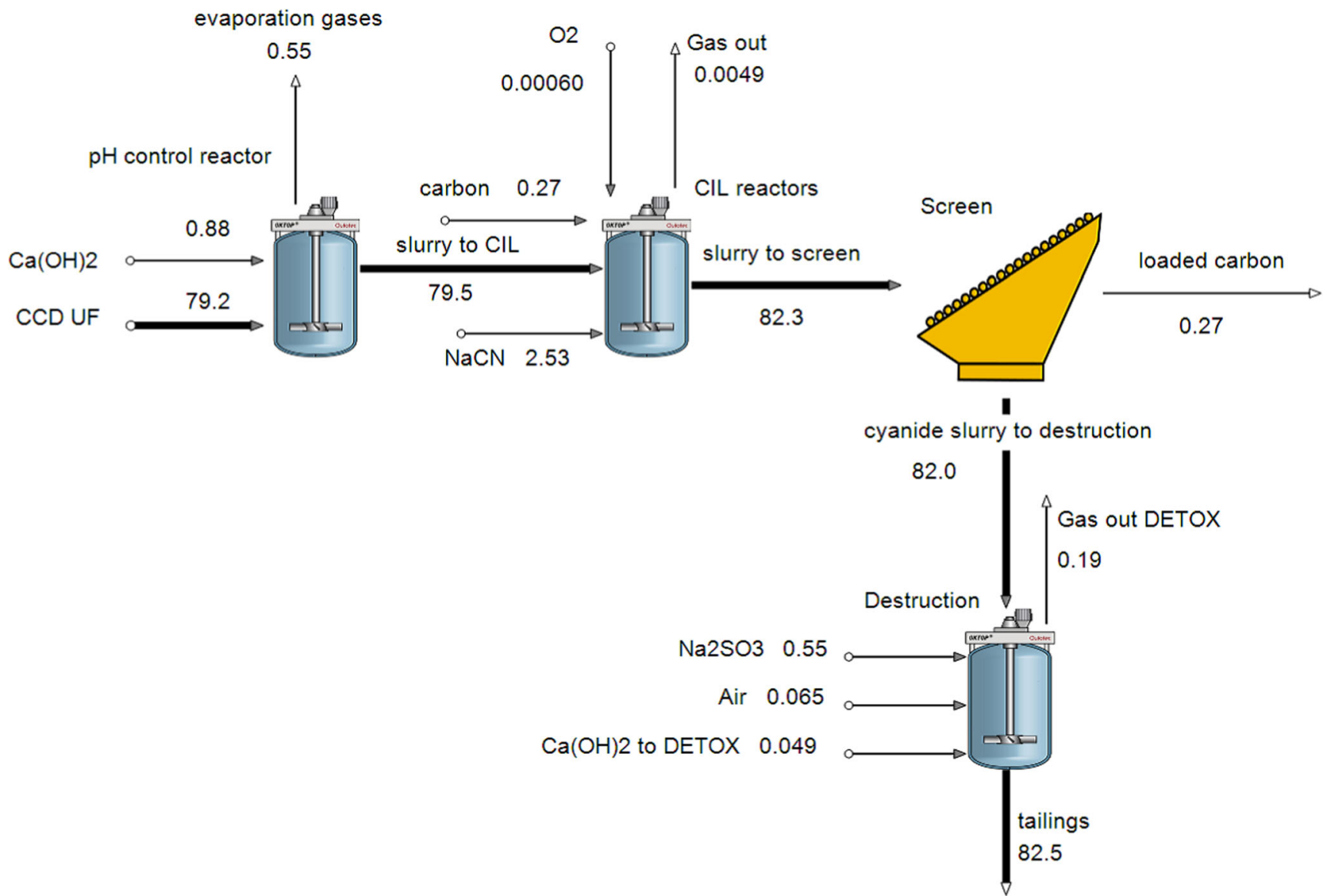

Fig. 3 The cyanidation simulation flowsheet for pressure oxidized refractory gold concentrate, showing mass balance (t/h) for each flow with ca. $10,000 \mathrm{~kg} /$ a gold production 


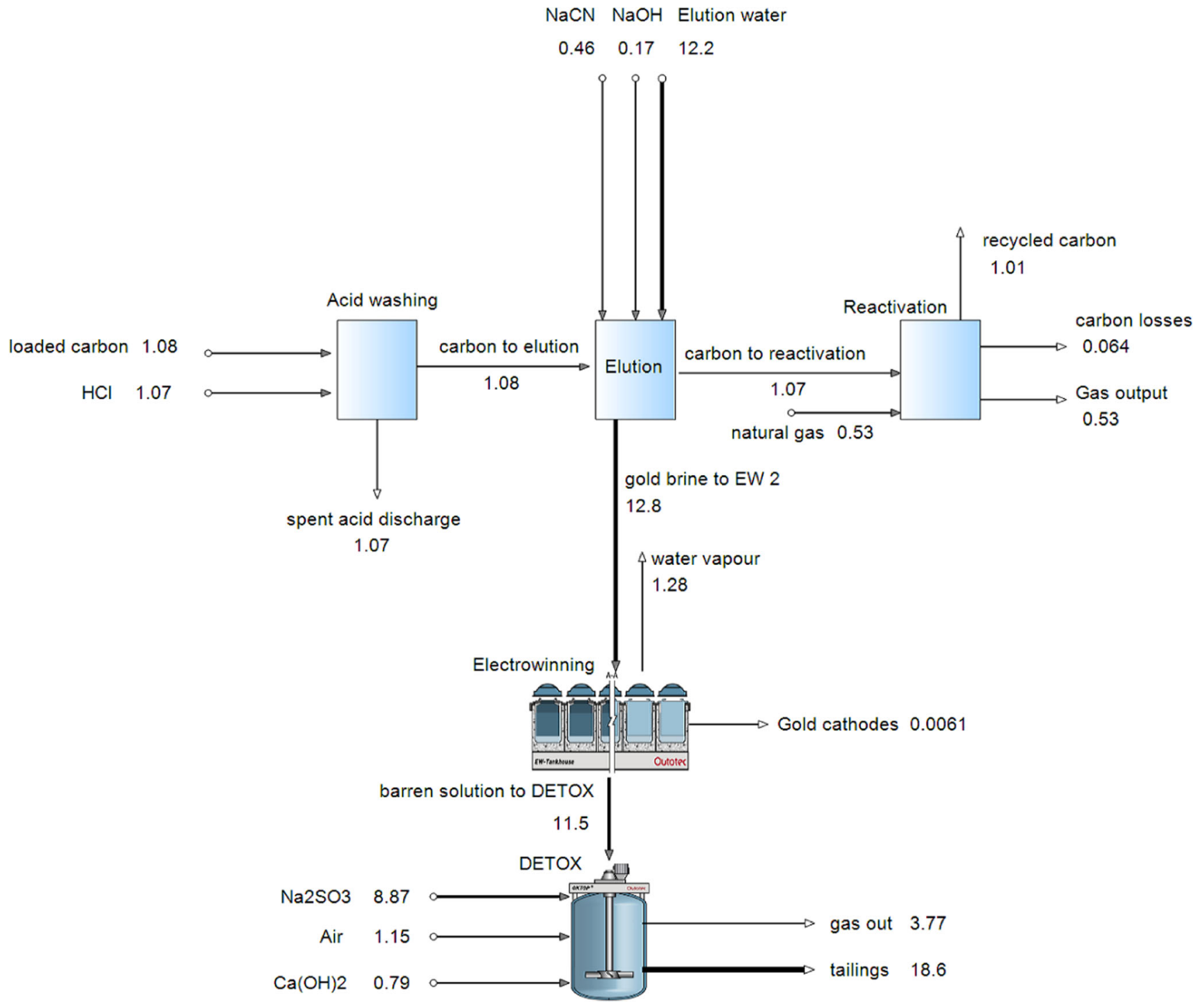

Fig. 4 The flowsheet of gold recovery from activated carbon originating from cyanidation, showing mass balance ( $\mathrm{t} / \mathrm{h})$ for each flow with ca. $10,000 \mathrm{~kg} / \mathrm{a}$ gold production

The parameters used in the simulation are shown in Table 3. Some of the parameters are used to control concentrations in the reactors, etc. Other parameters are not effectively used in the simulation but are compared with the results obtained from the simulation.

The main principles and observations of the simulated cyanidation are described in the following sections.

\subsubsection{Gold recovery}

The simulated gold recovery from the feed material was found to be $98.5 \%$. This is based on $99.8 \%$ leaching and $100 \%$ adsorption into carbon during instant recovery by CIL. This instant recovery on carbon allows minimization of gold losses into (i) the leach residue or (ii) the washing waters of the leach residue. In fact, no washing of the leach residue is conducted in cyanidation; the leach residue is discharged into a tailings pond after detoxification, from where the solution can be partially recycled back to the process.

\subsubsection{Cyanide consumption}

In the current simulation, the cyanide consumption in the CIL unit was found to be $0.98 \mathrm{~kg} / \mathrm{t}$ of concentrate. This is higher than typical cyanide consumptions $(0.25$ to $0.75 \mathrm{~kg} /$ t) for free-milling gold ores (Marsden and House 2006). However, when the feed material contains significant amounts of cyanide consumers and/or high silver content (i.e., $20 \mathrm{~g} / \mathrm{t}$ ), cyanide consumption may increase up to 1 to $2 \mathrm{~kg} / \mathrm{t}$ (Marsden and House 2006). 
Table 3 The parameters used in the simulation of the cyanidation process

\begin{tabular}{|c|c|c|c|c|}
\hline Unit process & Parameter & Value & $\begin{array}{l}\text { Control } \\
\text { unit }\end{array}$ & Reference \\
\hline \multicolumn{5}{|c|}{ Controlled parameters } \\
\hline CIL reactors & $\begin{array}{l}\mathrm{NaCN} \\
\quad \text { concentration }\end{array}$ & $0.5 \mathrm{~g} / \mathrm{L}$ & $\begin{array}{l}\mathrm{CIL} \\
\text { reactors }\end{array}$ & Marsden and House (2006) \\
\hline CIL reactors & $\begin{array}{l}\text { Solids } \\
\text { concentration }\end{array}$ & $35 \%$ & $\begin{array}{l}\mathrm{CIL} \\
\quad \text { reactors }\end{array}$ & Marsden and House (2006) \\
\hline CIL reactors & Activated carbon & $5 \mathrm{~g} / \mathrm{L}$ & $\begin{array}{l}\mathrm{CIL} \\
\text { reactors }\end{array}$ & Marsden and House (2006) \\
\hline CIL reactors & Gold loading & $\begin{array}{l}5-10 \mathrm{~kg} \mathrm{Au} / \mathrm{t} \mathrm{car-} \\
\text { bon }\end{array}$ & $\begin{array}{l}\mathrm{CIL} \\
\quad \text { reactors }\end{array}$ & Marsden and House (2006) \\
\hline $\begin{array}{l}\text { Cyanide } \\
\text { destruc- } \\
\text { tion }\end{array}$ & $\mathrm{SO}_{2}^{-}$consumption & $\begin{array}{l}3-4 \mathrm{~kg} \text { per } 1 \mathrm{~kg} \\
\text { free cyanide }\end{array}$ & Destruction & Marsden and House (2006) \\
\hline $\begin{array}{l}\text { Acid } \\
\text { washing }\end{array}$ & $\mathrm{HCl}$ concentration & $1-5 \%$ & $\begin{array}{l}\text { Acid } \\
\text { washing }\end{array}$ & Marsden and House (2006) \\
\hline $\begin{array}{l}\text { Acid } \\
\text { washing }\end{array}$ & Acid consumption & $25-50 \mathrm{~kg} / \mathrm{t}$ carbon & $\begin{array}{l}\text { Acid } \\
\text { washing }\end{array}$ & Mular et al. (2002) \\
\hline $\begin{array}{l}\text { Elution } \\
\text { AARL }\end{array}$ & $\begin{array}{l}\mathrm{NaCN} \\
\quad \text { concentration }\end{array}$ & $20-50 \mathrm{~g} / \mathrm{L}$ & Elution & Marsden and House (2006) \\
\hline $\begin{array}{l}\text { Elution } \\
\text { AARL }\end{array}$ & $\begin{array}{l}\mathrm{NaOH} \\
\quad \text { concentration }\end{array}$ & $10-15 \mathrm{~g} / \mathrm{L}$ & Elution & Marsden and House (2006) \\
\hline \multicolumn{5}{|c|}{ Other parameters } \\
\hline $\begin{array}{l}\mathrm{pH} \text { control } \\
\text { reactor }\end{array}$ & $\mathrm{pH}$ & $10.5-11$ & & Marsden and House (2006) \\
\hline CIL reactors & Temperature & $25^{\circ} \mathrm{C}$ & & Marsden and House (2006) \\
\hline CIL reactors & Lime consumption & $13 \mathrm{~kg} / \mathrm{t}$ solids & & Fleming et al. (2008) \\
\hline CIL reactors & $\begin{array}{l}\mathrm{NaCN} \\
\quad \text { consumption }\end{array}$ & $1 \mathrm{~kg} / \mathrm{t}$ solids & & $\begin{array}{l}\text { Fleming et al. (2008), Marsden } \\
\text { and House (2006) }\end{array}$ \\
\hline CIL reactors & $\begin{array}{l}\text { Activated carbon } \\
\text { consumption }\end{array}$ & $20-40 \mathrm{~g} / \mathrm{t}$ ore & & Marsden and House (2006) \\
\hline $\begin{array}{l}\text { Cyanide } \\
\text { destruc- } \\
\text { tion }\end{array}$ & $\mathrm{pH}$ & 9 & & Marsden and House (2006) \\
\hline $\begin{array}{l}\text { Cyanide } \\
\text { destruc- } \\
\text { tion }\end{array}$ & $\mathrm{CuSO}_{4}$ catalyst & $30-90 \mathrm{Cu}^{2+} \mathrm{g} / \mathrm{t}$ & & Marsden and House (2006) \\
\hline $\begin{array}{l}\text { Acid } \\
\text { washing }\end{array}$ & Temperature & $80^{\circ} \mathrm{C}$ & & Marsden and House (2006) \\
\hline $\begin{array}{l}\text { Elution } \\
\text { AARL }\end{array}$ & Temperature & $110-120^{\circ} \mathrm{C}$ & & Marsden and House (2006) \\
\hline $\begin{array}{l}\text { Elution } \\
\text { AARL }\end{array}$ & Pressure & $170-200 \mathrm{kPa}$ & & Marsden and House (2006) \\
\hline Reactivation & Temperature & $750^{\circ} \mathrm{C}$ & & Marsden and House (2006) \\
\hline Gold EW & Au concentration & $10 \mathrm{~g} / \mathrm{L}$ & & Marsden and House (2006) \\
\hline Gold EW & $\begin{array}{l}\mathrm{NaCN} \\
\quad \text { concentration }\end{array}$ & $2 \%$ & & Marsden and House (2006) \\
\hline Gold EW & $\begin{array}{l}\mathrm{NaOH} \\
\quad \text { concentration }\end{array}$ & $0.5 \%$ & & Marsden and House (2006) \\
\hline Gold EW & Temperature & $80^{\circ} \mathrm{C}$ & & Marsden and House (2006) \\
\hline
\end{tabular}

\subsubsection{Lime consumption}

Lime, $\mathrm{Ca}(\mathrm{OH})_{2}$, is the preferred chemical for $\mathrm{pH}$ control in cyanidation. Typical concentrations of $0.15-0.25 \mathrm{~g} / \mathrm{L}$ of calcium hydroxide are used, corresponding to lime consumptions of $0.15-0.5 \mathrm{~kg} / \mathrm{t}$ of ore (Marsden and House 2006). However, these consumption values are for non-acidic- or non-alkaliconsuming ores. In the studied system, POX was run at high acidity (see Sect. 3.1) to support higher gold extraction from preg-robbing raw material-therefore also notably higher lime consumption was observed $(30.6 \mathrm{~kg} / \mathrm{t}$ of concentrate). This is exceptionally high level; however, as high as $13 \mathrm{~kg} / \mathrm{t}$ has also been reported by Fleming et al. (2008). In the end, the consumption of $\mathrm{Ca}(\mathrm{OH})_{2}$ needs to be optimized vs. gold value; however, in the current study, the high gold extraction was emphasized. 


\subsubsection{Activated carbon}

Acid washing and elution processes are performed as batch processes. The amount of carbon was calculated in the CIL unit process as fresh carbon and the simulation predicts the required amount of carbon in the mass balance to be $0.27 \mathrm{t} / \mathrm{h}$, which can be circulated in the process up to 300 times. This could be then estimated as $0.9 \mathrm{~kg} / \mathrm{h}$ carbon requirement. The general industry average for carbon consumption in CIL system is 20 to $40 \mathrm{~g} / \mathrm{t}$ of ore (Marsden and House 2006). Carbon is lost in the process due to attrition.

\subsubsection{Detoxification}

Due to the formation of sulfuric acid, lime is added into the system to maintain the preferred $\mathrm{pH}$ value of 9. The consumption of sulfur dioxide is $3-4 \mathrm{~kg} \mathrm{SO}_{2}^{-}$per $1 \mathrm{~kg}$ free cyanide (Marsden and House 2006). The consumption value was used to set the $\mathrm{SO}_{2}$ concentration in the solution. Lime is added to the system to maintain the $\mathrm{pH}$; the consumption was $1.7 \mathrm{~kg} / \mathrm{t}$ of concentrate in the leaching simulation and $27.6 \mathrm{~kg} / \mathrm{t}$ concentrate in the recovery simulation.

\subsection{Halogen leaching simulation flow sheet}

The flowsheet of halogen leaching (Fig. 5) is built based on the work published in different patents by Lalancette (2009), Lalancette et al. (2015a), Lalancette et al. (2015b), as well as on the experimental work by Lemieux et al. (2014) and De Michelis et al. (2013). In the process (SCE2), POX-treated raw material is subjected to a halogen leaching process. The oxidized concentrate $(79.2 \mathrm{t} / \mathrm{h})$ is routed to gold leaching reactor(s) without $\mathrm{pH}$ adjustment as acidic conditions apply after POX. Gold extraction in leaching has been reported to be $98 \%$ for $2 \mathrm{~h}$ leaching (Lalancette et al. 2015b), increasing to $99 \%$ for $5 \mathrm{~h}$ leaching. After leaching, the leach residue is separated and the gold-enriched pregnant-leach-solution (PLS) $(72.2 \mathrm{t} / \mathrm{h}) \mathrm{di}-$ rected to gold recovery by silica adsorption (Lalancette et al. $2015 \mathrm{~b}$ ). The reduced gold on silica is separated by filtration. The leach residue is washed and the filtrate recycled back to leaching. The washing waters from the leach residue and neutralization residue washing are collected for evaporation, where a concentrated brine solution $(28.8 \mathrm{t} / \mathrm{h})$ is produced. The neutralization unit process was shown to consume $0.80 \mathrm{t}$ $\mathrm{Ca}(\mathrm{OH})_{2} / \mathrm{h}$ and to produce a hydroxide residue that has to be

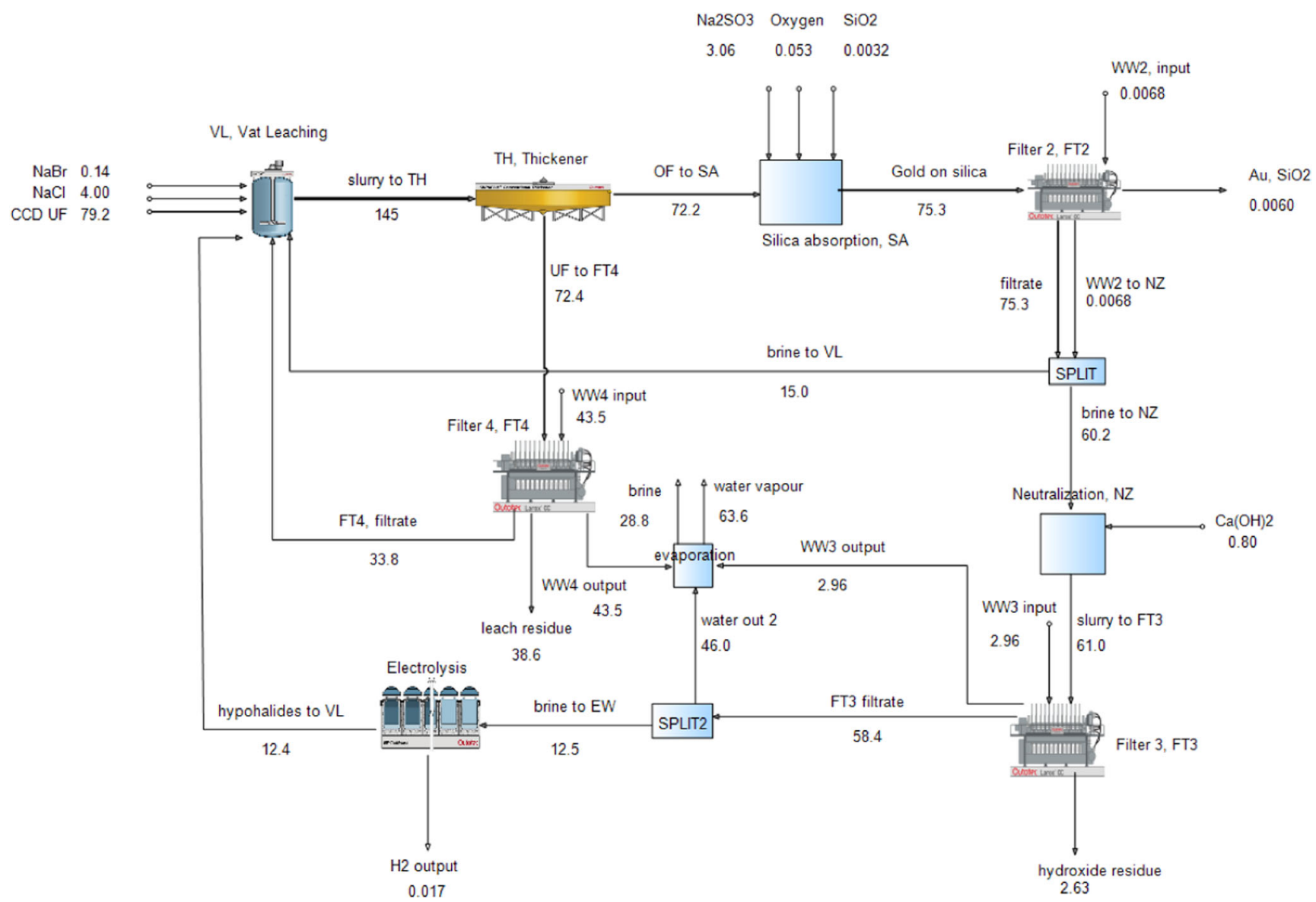

Fig. 5 The flowsheet of halogen leaching simulation for pressure oxidized refractory gold concentrate, showing mass balance ( $t / h)$ for each flow with ca. $10,000 \mathrm{~kg} / \mathrm{a}$ gold production 
disposed of. The chloride solution $(12.5 \mathrm{t} / \mathrm{h})$ is recycled back to leaching through hypohalide electrolysis.

The mass balance for each unit in halogen leaching flowsheet (SCE2) is shown in Fig. 5. The process parameters used in the simulation are listed in Table 4. Parameters used in simulation control are shown separately from other controls. Filter and thickener controls are standard controls for internal models found in HSC Sim equipment models.

The main principles and observations of the simulated halogen leaching are described in the following sections.

\subsubsection{Gold recovery}

In the SCE2 process, the gold extraction values are based on Lalancette et al. (2015a), Lalancette et al. (2015b), and Lemieux et al. (2014), reported to be from $95 \%$ to as high as $98 \%$ for 2-h leaching. For refractory-type material, longer leaching times can be required, thus also expecting higher gold extraction. Different to cyanidation, the gold halide leaching in SCE2 does not have in situ gold recovery, but gold recovery is conducted after $\mathrm{S} / \mathrm{L}$ separation by adsorption to silica, with reported recovery of as high as $99.98 \%$ (Lalancette et al. 2015b). According to these values, the simulation predicts $87.3 \%$ gold recovery. The low total Au recovery is explained by the following facts:

- In the studied case, in total, $1 \%$ of gold is lost to leach residue.
- There is no instant gold recovery in the halide process. This causes challenge as the gold present in the PLS also ends up to the moisture of the leach residue. The amount of washing water in filtration is limited $\left(1.5 \mathrm{~m}^{3} / \mathrm{t}\right.$ solids $)$ to keep the process water balance. Therefore, minor amount of PLS, and gold, is always present in the residue.

- Also, minor amount gold does not dissolve from the raw material.

- The used washing water $\left(1.5 \mathrm{~m}^{3} / \mathrm{t}\right.$ solids $)$ displaces some of the gold containing PLS at the filter; this brings along $11 \%$ of soluble gold with it to the evaporation stage. In SCE2, the latter is partly lost due to precipitation to leaching residue that can be prevented by washing the residue first with halide containing washing solution.

\subsubsection{Process design aspects in halogen leaching}

In the halogen process, halogen gases are produced in situ by redox control. This makes it possible to produce only the required amount of gases and circulate the halogens as hypohalides. The flowsheet was developed according to the literature; however, some modifications were made. Some of the gold-depleted solution was used to maintain the solids concentration in the leaching in order to recycle chlorides as early as this stage. Due to water
Table 4 Parameters used in simulation of the halogen leaching process

\begin{tabular}{|c|c|c|c|c|}
\hline Unit process & Parameter & Value & Control unit & Reference \\
\hline \multicolumn{5}{|c|}{ Controlled parameters } \\
\hline Leaching & $\mathrm{NaCl}$ concentration & $60 \mathrm{~g} / \mathrm{L}$ & Leaching & $\begin{array}{l}\text { Lalancette et al. } \\
\text { (2015a) }\end{array}$ \\
\hline Leaching & $\mathrm{NaBr}$ concentration & $2 \mathrm{~g} / \mathrm{L}$ & Leaching & $\begin{array}{l}\text { Lalancette et al. } \\
\text { (2015a) }\end{array}$ \\
\hline Leaching & Solids concentration & $20 \%$ & Split 1 & $\begin{array}{l}\text { Lalancette et al. } \\
\text { (2015a) }\end{array}$ \\
\hline $\begin{array}{l}\text { Silica } \\
\text { adsorption }\end{array}$ & Gold loading & $30 \%$ & $\begin{array}{l}\text { Silica } \\
\quad \text { adsorption }\end{array}$ & $\begin{array}{l}\text { Lalancette et al. } \\
\text { (2015a) }\end{array}$ \\
\hline \multicolumn{5}{|l|}{ Other parameters } \\
\hline Leaching & $\mathrm{pH}$ & 1.5 & & $\begin{array}{l}\text { Lalancette et al. } \\
\quad(2015 b)\end{array}$ \\
\hline Leaching & Temperature & $40-50{ }^{\circ} \mathrm{C}$ & & $\begin{array}{l}\text { Lalancette et al. } \\
\text { (2015a) }\end{array}$ \\
\hline Filtration & Filtration efficiency & $96 \%$ & & HSC Filter standard \\
\hline Filtration & Filtration cake moisture & $25 \%$ & & HSC Filter standard \\
\hline Filtration & Washing water amount & $\begin{array}{l}1.5 \mathrm{~m}^{3} / \mathrm{t} \text { of } \\
\text { solids }\end{array}$ & & HSC Filter standard \\
\hline Thickener & $\begin{array}{c}\text { Solid conc. in } \\
\text { underflow }\end{array}$ & $40 \%$ & & $\begin{array}{l}\text { HSC Thickener } \\
\text { standard }\end{array}$ \\
\hline $\begin{array}{l}\text { Silica } \\
\text { absorption }\end{array}$ & $\mathrm{pH}$ & 1.5 & & $\begin{array}{l}\text { Lalancette et al. } \\
\text { (2015a) }\end{array}$ \\
\hline Neutralization & $\mathrm{pH}$ & 6 & & Estimation \\
\hline
\end{tabular}


accumulation, an evaporation step was added to produce highchloride brine, which could possibly be used in leaching.

\subsubsection{Leach residue washing —water balance-environmental regulations for LR}

Due to challenges observed in S/L separation in halide process, different options for leach residue washing were simulated. The presented flowsheet shows the option, where accumulating water is evaporated in order to achieve concentrated brine, which could be recycled back to leaching.

Three other options were investigated for leach residue (LR) washing, a schematic flowsheet presented in Fig. 6:

Case 1: LR is not washed.

Case 2: LR is washed with water.

Case 3: LR is washed with PLS after gold recovery.

In all cases, $1 \%$ of the gold left in residues is lost because this gold is not leached in the leaching stage. In addition, part of the leached gold in case $1(0.02 \mathrm{~g} / \mathrm{L})$ is lost with solids as moisture, due to the fact that the washing liquids are not circulated back to the leaching reactors, as in cases 2 and 3 . However, by not washing the residues and circulating these waters to the process, the accumulation of waters can be avoided. In case 2, accumulation of water in the process was observed. Around $92.2 \mathrm{t} / \mathrm{h}$ of solution needs to be taken out from the process. This solution has a chloride concentration of $35.4 \mathrm{~g} / \mathrm{L}$, which means that further treatment is necessary before the solution can be either used as process water or disposed of. In addition, the chemical consumption of $\mathrm{NaBr}$ and $\mathrm{NaCl}$ is higher along the chemicals bled out of the process. In case 3 , the leach residue is washed with filtrate of $\mathrm{Au} / \mathrm{SiO}_{2}$ product filter. In this case too, water accumulation is avoided to some degree. However, some gold is lost to the residues. These alternatives concluded that it would be best to gather washing waters to evaporation, in order to produce a concentrated brine, creating a possibility to recycle chloride chemicals.

\subsubsection{Neutralization residue—water treatment}

The neutralization residue is washed, and the filtrate is circulated back to the process. The moisture of the neutralization cake is $25 \%$, mostly water as the washing efficiency is $96 \%$. The chloride concentration in the presented flowsheet is $1.38 \mathrm{~g} / \mathrm{L}$ in the solid residue flow and the washing waters have $7.44 \mathrm{~g} / \mathrm{L}$ of $\mathrm{Cl}^{-}$. Therefore, in addition to leach residue, the process produces a waste fraction with ca. $345 \mathrm{ppm}$ of $\mathrm{Cl}^{-}$, which is well below environmental regulations of landfill qualifications. The chloride concentration limits for conventional landfill are 15,000 ppm and for hazardous landfill 25,000 ppm in Finland (Wahlström et al. 2006).

\subsubsection{Tank house operation}

The water balance also affects the operation of hypochlorite electrolysis. The electrolysis of hypochlorite can be energyconsuming. Therefore, the more process liquids are subjected to electrolysis, the more energy is consumed in the process. The actual patent describing the halogen process does not describe the parameters used for hypohalide electrolysis; thus, it was assumed to be a similar process to other hypohalide electrolysis processes presented in the literature.

According to the Childers et al. (2007) patent for producing hypochlorite by electrolysis, the electric current is controlled to keep power consumption below $2.5 \mathrm{kWh} /$ pound of hypochlorite produced and $2.5 \mathrm{~kg}$ of $\mathrm{NaCl}$ is consumed to produce

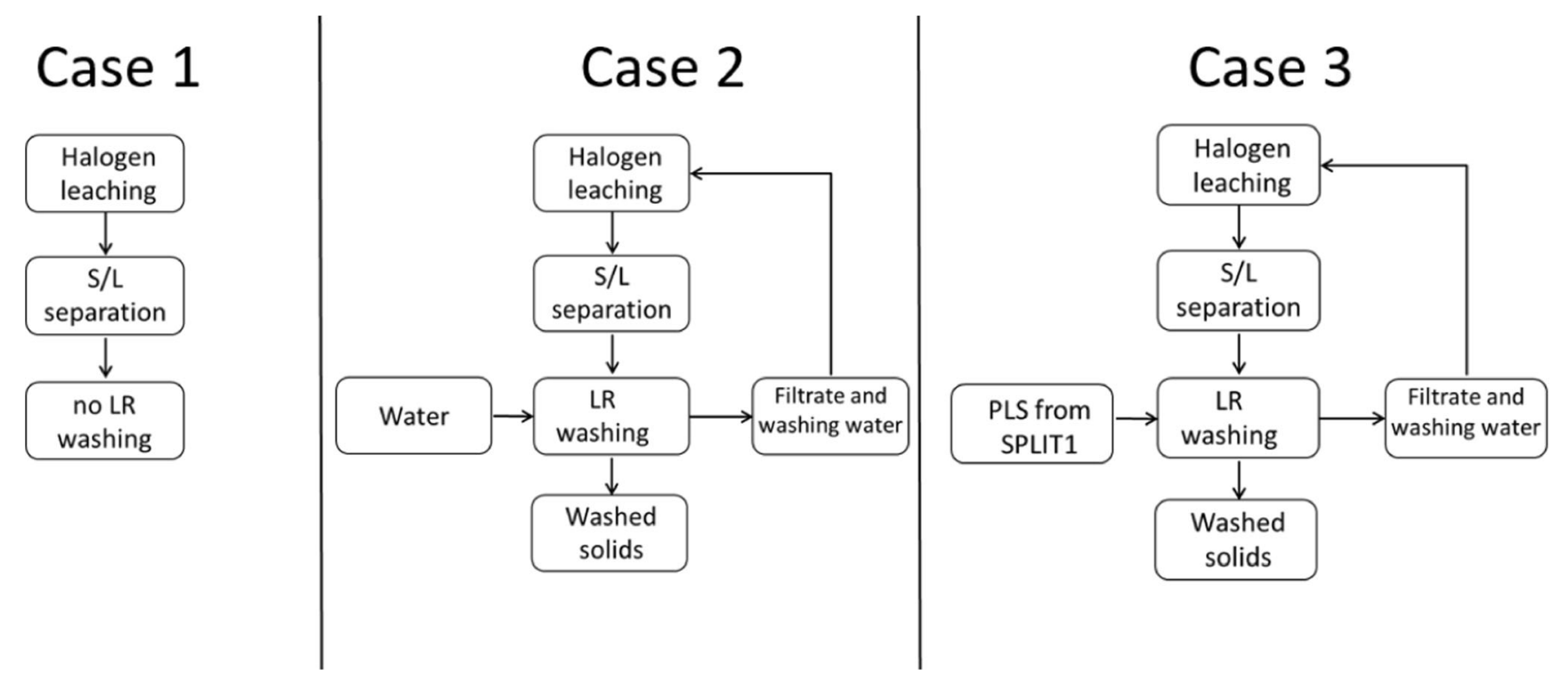

Fig. 6 The schematics of cases investigated to avoid water accumulation in the halogen process 
$1 \mathrm{~kg} \mathrm{NaOCl}$. Bashtan et al. (1999) report consumption of $2.4 \mathrm{~kg} \mathrm{NaCl}$ to produce $1 \mathrm{~kg}$ of $\mathrm{NaOCl}$ and power consumption of $3.1 \mathrm{kWh} / \mathrm{kg} \mathrm{NaOCl}$ produced. In addition, Kuhn and Lartey (1975) reported the $\mathrm{NaCl}$ consumption of $3-3.5 / \mathrm{kg} \mathrm{NaOCl}$ produced and power consumption of 4.4$8.8 \mathrm{kWh} / \mathrm{NaOCl} \mathrm{kg}$. An average value of $3.1,4.4$, and $5.5 \mathrm{kWh} / \mathrm{kg} \mathrm{NaOCl}$, corresponding to $16 \mathrm{MJ} / \mathrm{kg} \mathrm{NaOCl}$, was used to estimate the power consumption of electrolysis.

\subsubsection{Chemical consumption}

The $\mathrm{NaBr}$ concentration in leaching should be $2 \mathrm{~g} / \mathrm{L}$, and the reported $\mathrm{Cl}^{-}$concentration in PLS is $32.32 \mathrm{~g} / \mathrm{L}$ (Lalancette et al. 2015a), which corresponds to a $\mathrm{NaCl}$ concentration of $60 \mathrm{~g} / \mathrm{L}$. These concentration values were used in the simulation to control the inputs of $\mathrm{NaBr}$ and $\mathrm{NaCl}$ chemicals, and thus in the presented flowsheet, the $\mathrm{NaBr}$ consumption is predicted to be $0.14 \mathrm{t} / \mathrm{h}$ and $\mathrm{NaCl}$ consumption $4 \mathrm{t} / \mathrm{h}$. These values correspond to $5 \mathrm{~kg}$ $\mathrm{NaBr} / \mathrm{t}$ and $140 \mathrm{~kg} \mathrm{NaCl} / \mathrm{t}$ concentrate. These levels of consumptions are significantly higher compared to cyanidation. However, electrolysis provides a method to partially recycle the chlorides. Moreover, due to lack of published data, the solid concentration in leaching is given as $20 \%$, which corresponds to higher solution volumes in leaching and thus higher chemical consumption.

\subsubsection{Second gold recovery process}

As the total gold recovery in halogen leaching was notably low, the addition of a second gold silica adsorption step, described herein as SCE2b, was simulated for the recovery of gold from wash water (WW4) assuming no gold precipitation during leach residue washing. In this way, a higher total Au recovery of $98.5 \%$ could be predicted by the simulation. However, the use of a second recovery unit has not been reported in the literature.

\subsection{Comparison of mass (and energy balance) in SCE 1 and SCE2}

The values presented in the investigated scenarios are for a throughput of $40.2 \mathrm{t}$ of concentrate. This corresponds to $28.6 \mathrm{t}$ of dry concentrate after POX, routed to gold leaching as $36 \%$ slurry. It can be seen that, in general, the consumables in halogen leaching were higher compared to cyanide, see Table 5. However, the lime consumption is higher in cyanidation due to the alkaline nature of the cyanidation process whereas, in halogen leaching, lime is used only for neutralizing the solutions. The high water consumption in halogen leaching originates from the need to wash chloride out of the leach residue and neutralization solids. The residues were washed in filters using $1.5 \mathrm{~m}^{3}$ washing water/t of solids, with $96 \%$ efficiency.
The electricity consumption was evaluated based on the simulation model by taking into account the most electric energy-consuming unit processes. The equations and calculation methodology are presented in detail in the ESM S1.4. The higher electricity consumption in halogen leaching (SCE2) compared to cyanidation (SCE 1) can be explained by the hypohalide electrolysis (ESM S1.4), being an average of $4.3 \mathrm{kWh}$ per $\mathrm{kg}$ of hypochlorite produced.

The observations here highlight some of the challenges related to simulation of development-stage cyanide-free processes - although the evaluation of these processes is necessary prior to upscaling to industrial scale, there is only limited information compared to proven technologies (the process flow sheets have not been published or designed in detail), which may lead to large variation in the estimation of the final mass and energy balances and furthermore in the life cycle assessment. It is evident that the halogen process (SCE2) suffers from handling the washing waters and gold lost to residues or sidestreams, as gold leaching and recovery are conducted in separate stages. The benefit of cyanidation (SCE1) is the simultaneous recovery of gold on carbon by the CIL leaching method, creating a smaller volume of gold rich solution in the elution process as well as production of detoxified residues without washing requirements.

\section{Life cycle assessment}

\subsection{Assumptions}

Life cycle assessment (LCA) can be used to evaluate the environmental impact of a product, a process, or an activity during its lifetime from raw material to end-of-life. LCA is essentially an environmental tool, which can be adapted to evaluate the environmental impacts of metallurgical processes. ISO 14040 and ISO 14044 standards describe the methodology of LCA (ISO 14040 2006; ISO 14044 2006). The use of LCA methodology is increasingly used to assess the environmental sustainability of metallurgical processes (Norgate et al. 2007; Norgate and Jahanshahi 2010), however, few studies about gold processes have been presented (Norgate and Haque 2012). The method used in this study, combining HSC Sim and $\mathrm{GaBi}$ software, has been adopted by Llamas et al. (2019), Ghodrat et al. (2017), Reuter et al. (2015) and Kotiranta et al. (2015). However, the methodology has not yet been excessively used to evaluate hydrometallurgical gold processing.

\subsubsection{LCA assumptions}

In this study, LCA has been performed on two simulation models, one consisting of POX and cyanidation (SCE1), and the other POX and halogen leaching (SCE 2), both utilizing a refractory gold concentrate as the raw material. The 
Table 5 Comparison of input quantities to treat $40.2 \mathrm{t}$ of concentrate in SCE1 and SCE2

\begin{tabular}{llll}
\hline Input & SCE1: POX and cyanidation & SCE2:POX and halogen leaching & Unit \\
\hline Dry concentrate & 40.2 POX/28.6 leaching & 40.2 POX/28.6 leaching & $\mathrm{t}$ \\
Electricity & 25,277 & 30,579 & $\mathrm{MJ}$ \\
$\mathrm{Ca}(\mathrm{OH}) 2$ & 17.8 & 16.7 & $\mathrm{t}$ \\
Air & 0.5 & & $\mathrm{t}$ \\
Oxygen & 21.2 & 25.2 & $\mathrm{t}$ \\
$\mathrm{NaCN}$ & 0.1 & & $\mathrm{t}$ \\
$\mathrm{NaCl}$ & & 4.0 & $\mathrm{t}$ \\
$\mathrm{NaBr}$ & & 0.1 & $\mathrm{t}$ \\
Water & 268.9 & 309.7 & $\mathrm{t}$ \\
\hline
\end{tabular}

environmental indicators for each scenario are based on the mass balance produced with HSC Sim steady-state simulation (Chapter 3 and ESM S1.1.-S1.4.). The simulation produces a consistent life cycle inventory (LCI) (Llamas et al. 2019). HSC Sim is compatible with the GaBi LCA software, where LCI data from HSC-Sim is directly exported to. In GaBi software, the environmental indicators of global warming potential (GWP), acidification potential (AP), terrestrial eutrophication potential (EP), and water depletion (Water) are estimated. The LCI for both scenarios reference Finnish or European data in GaBi database.

\subsubsection{Functional unit}

In cyanidation scenario, gold is produced as cathode gold and in the halogen leaching as a silica adsorption product. The functional unit selected was $1 \mathrm{~kg}$ of produced gold. Both scenarios have the same input for POX and the leaching stage.

\subsubsection{System boundaries}

In this study, the system boundaries cover the primary raw materials and energy entering the POX and leaching unit processes up to when the product leaves the process as product, emission, or by-product as a gate-to-gate model of the refractory gold concentrate hydrometallurgical processing. The treatment and final disposing of waste streams is not included in the metallurgical simulation of the processes; thus, they are out of the system boundary of this study. However, the produced waste streams are discussed from environmental point of view. The processing route of gold and the boundaries for the LCA study are presented in Fig. 7.The geographical scope of the study is regional. The results of this study are indicative, as the scales, conditions, technologies, and operation of the modeled processes are based on literature information, not on industrial processes.

The HSC-Sim can be used for the normalization of flows. As mentioned, the flows were normalized to the production of $1 \mathrm{~kg} \mathrm{Au}$, on which the environmental indicators are based on.
The description of the LCI and the comparison of simulation model LCAs are discussed in the following sections.

\subsection{Inventory for LCA}

The inputs and outputs of the HSC Sim simulation model can be linked to corresponding flows in the GaBi database through the LCA Evaluation tool in HSC Sim. Table 6 lists the inventory data used for the LCA study of the simulations normalized to $1 \mathrm{~kg}$ of Au. The data was produced with HSC-Sim software, where the simulation models were based on data collected from the literature described in Table 2, Table 3, and Table 4. The electricity consumption in the halide process is higher due to hypohalide electrolysis, as stated previously. It can be seen that the halogen process inventory is scaled larger compared to cyanidation due to lower recoveries of gold; thus, more concentrate is needed from POX operation to leaching stage in order to produce $1 \mathrm{~kg}$ of gold. As a result, the environmental impact of gold leaching is greater in general. Nevertheless, the emissions are of the same magnitude in both processes. The improved gold recovery by addition of a second gold recovery unit (SCE2b) brings the halogen process more close to values of cyanidation (SCE1). The energy of cyanidation recovery process refers to the heating of the activated carbon reactivation kiln. In halogen leaching, the unspecified energy refers to the heat required mainly by not only the water evaporation unit but also in electrowinning and leaching. However, this flow was cutoff due to uncertainty of upstream process for the flow.

\subsection{Life cycle impact assessment}

The environmental impact indicators chosen for discussion in this study are presented in Fig. 8 for the SCE1, SCE2, and $\mathrm{SCE} 2 \mathrm{~b}$ processes. 


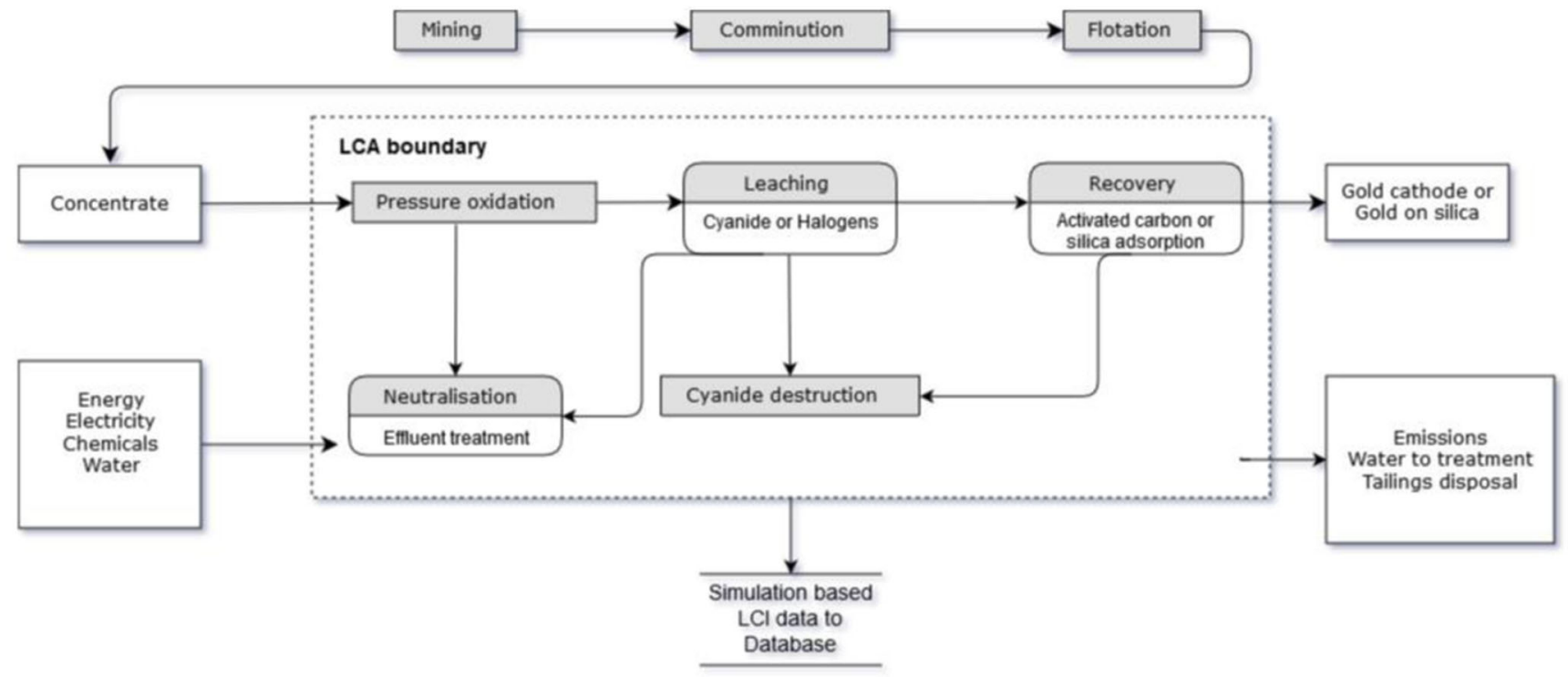

Fig. 7 The process route of gold from mining to product. The dashed line emphasizes the system boundary of the LCA conducted in this study. The simulated unit processes provide the LCI data

\subsubsection{GWP}

The GWP obtained in this study is $12.6 \mathrm{t} \mathrm{CO}_{2}-\mathrm{e} / \mathrm{kg} \mathrm{Au}$ for $\mathrm{SCE} 2$ and $10.3 \mathrm{t} \mathrm{CO}_{2}$-e/kg Au for SCE1 (Fig. 8a). The GWP estimated in halogen leaching is larger due to the lower recovery of gold $(87.3 \%)$, indicating that more concentrate needs to be processed in order to produce $1 \mathrm{~kg}$ of gold. Thus, the impact of POX increases the GWP. In the scenario with an additional gold recovery unit (SCE2b), the GWP is lower, at $11.5 \mathrm{t} \mathrm{CO} 2-\mathrm{e} / \mathrm{kg} \mathrm{Au}$, decreasing the difference in GWP between state-of-art cyanidation and development-stage halogen leaching from $2.3 \mathrm{t} \mathrm{CO} 2-\mathrm{e} /$ $\mathrm{kg} \mathrm{Au}$ to $1.2 \mathrm{t} \mathrm{CO} 2-\mathrm{e} / \mathrm{kg} \mathrm{Au}$. The difference in GWP is greatly affected by the differences in electricity consumption between SCE1 and SCE2, as hypohalide electrolysis was suggested to be energy-consuming. Also, it needs to be noted that $\mathrm{NaCl}$ is included in the halide leaching LCA, but input data for $\mathrm{NaCN}$ was not found in the database. However, the results here indicate that the difference between a development-stage halide process (SCE2) and state-of-art cyanidation (SCE1) can be decreased through the optimization and process development, to make the halide process competitive in terms of the carbon emissions.

\subsubsection{AP}

The inputs affecting acidification potential are the same in both SCE1 and SCE2, as are seen in Fig. 8b. However, in halogen leaching, the production of sodium chloride increases the AP. The simulation did not predict the output gas of $\mathrm{SO}_{\mathrm{x}}$ from the cyanide detoxification units, where sulfur dioxide is used as the reagent. Sulfur gases can be released from detoxification units, which might increase the acidification potential of cyanidation. In addition, the $\mathrm{NaCN}$ was not found in database and could have impact on SCE1 acidification potential.

\subsubsection{Terrestrial EP}

The eutrophication potential was found to be 1.7 times higher in halogen leaching compared to cyanidation, as shown in Fig. 8c, and this is affected by the $\mathrm{NO}_{\mathrm{x}}$ emissions. The EP of halide leaching is mostly due to $\mathrm{NaCl}$ production, which contributes $27.4 \%$ to the halogen leaching EP. Electricity consumption contributes $33.8 \%$ of the total eutrophication potential in cyanidation and $33.9 \%$ in halogen leaching. The EP can be lowered through efficient recycling of chloride chemicals in the plant.

\subsubsection{Water depletion (water)}

Water depletion describes the amount of water resources that is reduced. Water depletion was suggested to be higher in halogen leaching: $99.3 \mathrm{~kg}$ of water for halogen leaching compared with $77 \mathrm{~kg}$ of water for cyanidation, as shown in Fig. 8d. The difference is explained by the larger amount of process water consumed in halogen leaching due to the low solid concentration reported for leaching. In the cyanidation process, in contrast, the activated carbon method scales down the recovery process compared to halogen leaching, where large amounts of solution is directed to silica adsorption. The usage of fresh water can be lowered by providing a water purification plant and recovering the steam condensate from POX plant. 
Table 6 LCI produced with HSC-Sim simulation normalized to $1 \mathrm{~kg}$ of gold

\begin{tabular}{|c|c|c|c|c|c|c|}
\hline Input & Amount & Unit & Cutoff flow & Output & Amount & Unit \\
\hline \multicolumn{7}{|l|}{ POX, SCE1, and SCE2 } \\
\hline $\begin{array}{l}\text { Electricity (electric } \\
\text { power) }\end{array}$ & 3035.3 & $\mathrm{kWh}$ & & Concentrate & 17,875 & $\mathrm{~kg}$ \\
\hline Oxygen & 13,250 & $\mathrm{~kg}$ & & Carbon dioxide & 5843.8 & $\mathrm{~kg}$ \\
\hline Limestone & 9937.5 & $\mathrm{~kg}$ & & Nitrogen & 131 & $\mathrm{~kg}$ \\
\hline Process water & $131,187.5$ & $\mathrm{~kg}$ & & Oxygen & 2625 & $\mathrm{~kg}$ \\
\hline \multirow[t]{4}{*}{ Concentrate } & 25,125 & $\mathrm{~kg}$ & & $\begin{array}{l}\text { Process water (in } \\
\text { slurry) }\end{array}$ & $31,562.5$ & $\mathrm{~kg}$ \\
\hline & & & & Solid waste & 23,375 & $\mathrm{~kg}$ \\
\hline & & & & Water vapor & 41,875 & $\mathrm{~kg}$ \\
\hline & & & & Wastewater & 56,312 & $\mathrm{~kg}$ \\
\hline \multicolumn{7}{|l|}{ Cyanidation, SCE1 } \\
\hline Air & 41.3 & $\mathrm{~kg}$ & $*$ & Loaded carbon & 168.8 & $\mathrm{~kg}$ \\
\hline Activated carbon & 168.8 & $\mathrm{~kg}$ & $*$ & Nitrogen & 32.5 & $\mathrm{~kg}$ \\
\hline Calcium hydroxide & 550 & $\mathrm{~kg}$ & & Solid waste & 17,875 & $\mathrm{~kg}$ \\
\hline Concentrate & $17,893.8$ & $\mathrm{~kg}$ & & Water vapor & 434.3 & $\mathrm{~kg}$ \\
\hline Electricity & 1273.6 & $\mathrm{kWh}$ & & Wastewater & $33,687.5$ & $\mathrm{~kg}$ \\
\hline Oxygen & 0.4 & $\mathrm{~kg}$ & & & & \\
\hline Sodium cyanide & 17.5 & $\mathrm{~kg}$ & $*$ & & & \\
\hline Sodium sulfite & 51.9 & $\mathrm{~kg}$ & $*$ & & & \\
\hline Water & $33,406.3$ & $\mathrm{~kg}$ & & & & \\
\hline \multicolumn{7}{|l|}{ Recovery, SCE1 } \\
\hline Activated carbon & 177 & $\mathrm{~kg}$ & $*$ & Gold & 1 & $\mathrm{~kg}$ \\
\hline Air & 271.8 & $\mathrm{~kg}$ & $*$ & $\begin{array}{l}\text { Activated carbon [for } \\
\text { reuse] }\end{array}$ & 165.6 & $\mathrm{~kg}$ \\
\hline Calcium hydroxide & 129.5 & $\mathrm{~kg}$ & & Carbon dioxide & 12.8 & $\mathrm{~kg}$ \\
\hline Electricity & 83.4 & $\mathrm{kWh}$ & & $\begin{array}{l}\text { Hydrochloric acid [for } \\
\text { recovery] }\end{array}$ & 4.9 & $\mathrm{~kg}$ \\
\hline $\begin{array}{l}\text { Thermal energy } \\
\text { (heating) }\end{array}$ & 172.4 & MJ & & Nitrogen & 214.8 & $\mathrm{~kg}$ \\
\hline $\begin{array}{l}\text { Fuel, natural gas in } \\
\text { Finland }\end{array}$ & 86.9 & $\mathrm{~kg}$ & & Wastewater & 3219.7 & $\mathrm{~kg}$ \\
\hline Hydrochloric acid & 5.2 & $\mathrm{~kg}$ & & Water vapor & 687.9 & $\mathrm{~kg}$ \\
\hline Process water & 3513.1 & $\mathrm{~kg}$ & & & & \\
\hline Sodium cyanide & 75.4 & $\mathrm{~kg}$ & $*$ & & & \\
\hline Sodium hydroxide & 27.9 & $\mathrm{~kg}$ & & & & \\
\hline Sodium sulfite & 218 & $\mathrm{~kg}$ & $*$ & & & \\
\hline \multicolumn{7}{|c|}{ Halogen leaching, SCE2 } \\
\hline Electricity & 2598.4 & $\mathrm{kWh}$ & & Gold & 1 & $\mathrm{~kg}$ \\
\hline $\begin{array}{l}\text { Unspecified energy } \\
\text { (heating) }\end{array}$ & 130 & GJ & $*$ & Brine & $20,571.4$ & $\mathrm{~kg}$ \\
\hline Oxygen & 37.9 & $\mathrm{~kg}$ & & $\begin{array}{l}\text { Hydrogen } \\
\text { (Electrolytic steam) }\end{array}$ & 12.1 & $\mathrm{~kg}$ \\
\hline Calcium hydroxide & 571 & $\mathrm{~kg}$ & & Silica sand & 3.4 & $\mathrm{~kg}$ \\
\hline Concentrate & $20,428.6$ & $\mathrm{~kg}$ & & Sulfur dioxide & 0.002 & $\mathrm{~kg}$ \\
\hline Silica sand & 2.3 & $\mathrm{~kg}$ & & Solid waste & $22,121.4$ & $\mathrm{~kg}$ \\
\hline Sodium bromide & 100 & $\mathrm{~kg}$ & & Wastewater & 7371.4 & $\mathrm{~kg}$ \\
\hline Sodium chloride & 2857.1 & $\mathrm{~kg}$ & & Water vapor & $45,428.6$ & $\mathrm{~kg}$ \\
\hline Sodium sulfite & 300 & $\mathrm{~kg}$ & $\begin{array}{l}* \text { remarks the } \\
\text { cut-off flow }\end{array}$ & & & \\
\hline Process water & $71,104.9$ & $\mathrm{~kg}$ & & & & \\
\hline
\end{tabular}


a

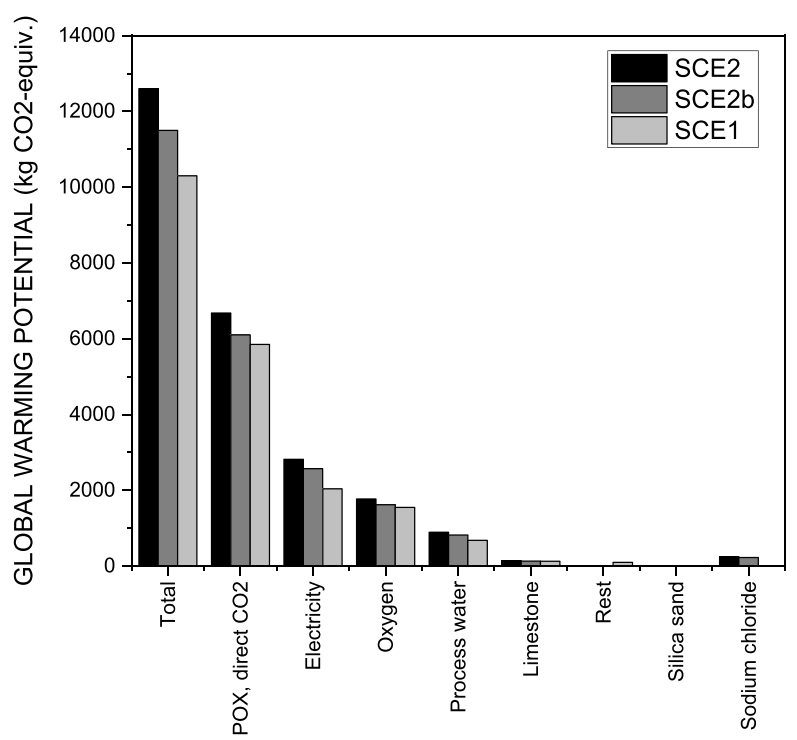

C

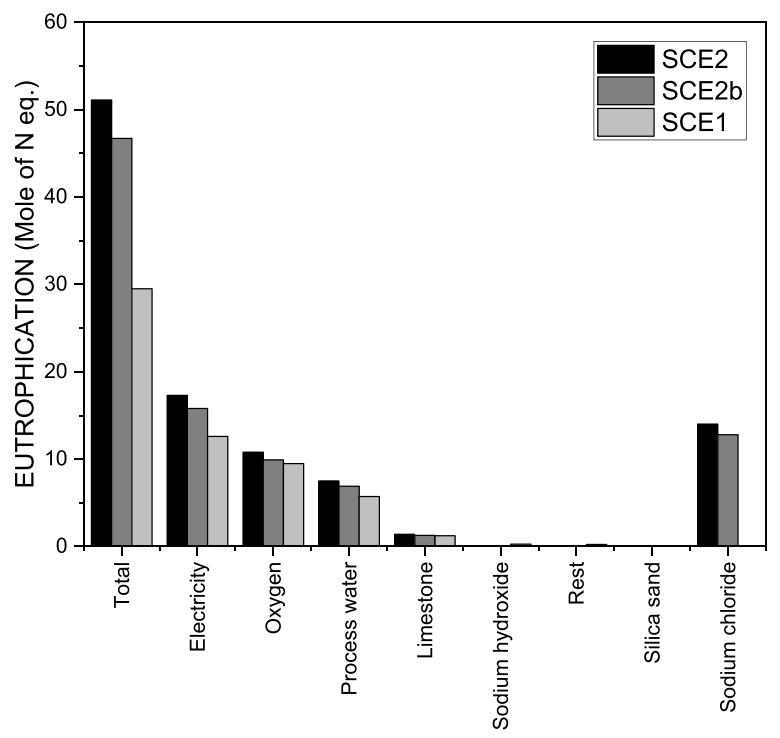

b

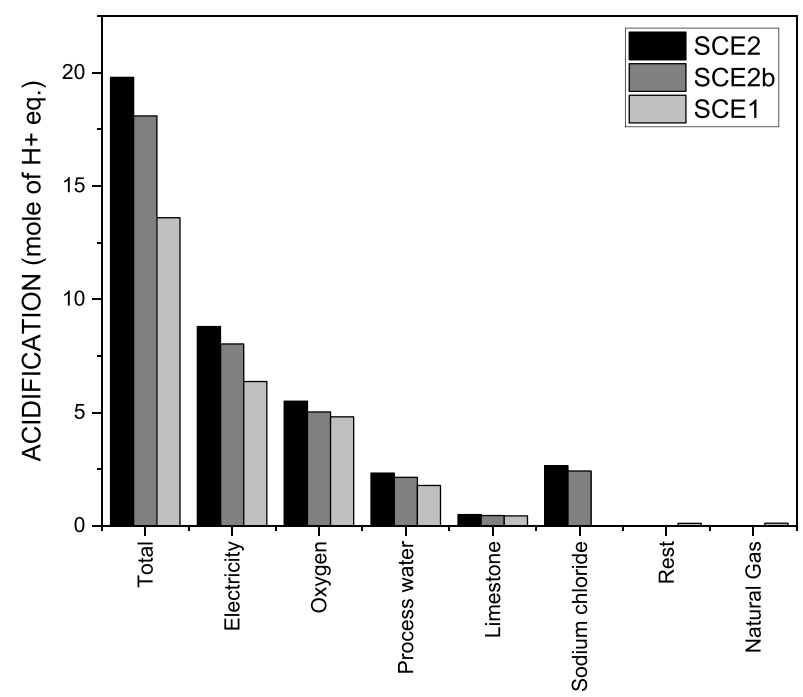

d

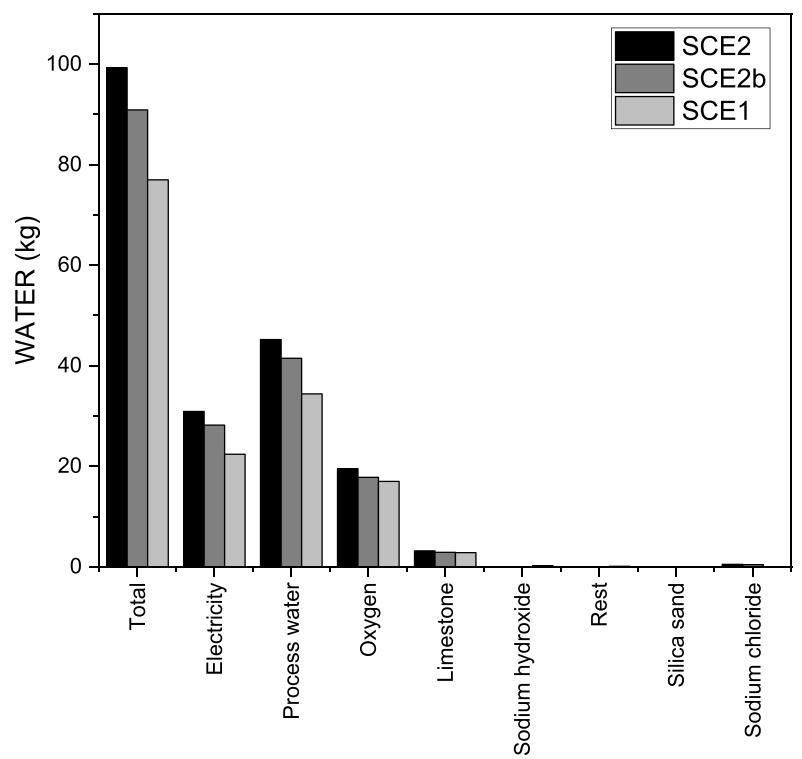

Fig. 8 Environmental impact indicators of POX followed by cyanidation or halogen leaching

\subsubsection{Environmental implications of process design}

The possible waste streams of hydrometallurgical processing are the solid wastes, gas discharges, and wastewaters. The aim of the processing is to produce; stable solid wastes that can be deposited safely, clean gases that can be released to the environment and purified wastewaters, which have acceptable concentrations of hazardous elements.

The composition of produced solid waste is affected by the mineralogy of the concentrate through unleached oxide and silica minerals and the produced neutralization precipitates. In this study, the concentrate includes a significant amount of arsenopyrite, which is oxidized for gold liberation. In the autoclave conditions, most of the $\mathrm{AsO}_{4}{ }^{-3}$ will precipitate as $\mathrm{FeAsO}_{4}$ (scorodite) and the rest of the arsenic will be precipitated in the neutralization stage as scorodite. The solubility of scorodite has been found to be low, less than $5 \mathrm{mg} \mathrm{As} / \mathrm{L}$; therefore, scorodite is considered to be the most stable arsenate compound suitable for arsenic disposal purposes. (Swash and Monhemius 1998) Most of the scorodite ends up into the leach residue and will be deposited into a tailings pond.

The other dissolved impurities during pressure oxidation are precipitated as hydroxides in the neutralization unit process. These include $\mathrm{CaSO}_{4} \cdot 2 \mathrm{H}_{2} \mathrm{O}, \mathrm{Cu}(\mathrm{OH})_{2} \mathrm{Ni}(\mathrm{OH})_{2} \mathrm{Al}$ $(\mathrm{OH})_{3}$ and jarosites such as $\mathrm{KFe}_{3}\left(\mathrm{SO}_{4}\right)_{2}(\mathrm{OH})_{6}$ 
$\mathrm{NaFe}_{3}\left(\mathrm{SO}_{4}\right)_{2}(\mathrm{OH})_{6}$ and $\left(\mathrm{H}_{3} \mathrm{O}\right) \mathrm{Fe}_{3}\left(\mathrm{SO}_{4}\right)_{2}(\mathrm{OH})_{6}$. These are also deposited into tailings pond.

The gold concentrate also contains $\mathrm{PbS}$ (Galena), $\mathrm{Cu}_{10} \mathrm{Fe}_{2} \mathrm{Sb}_{4} \mathrm{~S}_{13}$ (Tetrahedrite), and NiSb (Breithauptite), which include lead and antimony. In sulfuric acid, pressure oxidation lead precipitates as lead sulfate $\left(\mathrm{PbSO}_{4}\right)$. This precipitate will end up in the subsequent leaching step, i.e., cyanidation or halogen leaching, indicating that the pressure oxidation wastewaters or solids will not contain lead. Antimony minerals will also leach in the pressure oxidation and precipitate as $\mathrm{FeSbO}_{4}$ (Tripuhyite). Thus, the precipitate products $\left(\mathrm{FeAsO}_{4}, \mathrm{FeSbO}_{4}\right.$ and $\left.\mathrm{PbSO}_{4}\right)$ originating from pressure oxidation will end up into the leach residue, i.e., cyanidation tailings or halogen leaching solid waste after leaching residue washing. According to Multani et al. (2016), tripuhyite is the optimal form for antimony immobilization. Lead sulfate is known to be poorly soluble to water; however, slow release of lead to environment over a long period of time can be possible.

The main gaseous emissions predicted by the simulation and shown in the GWP estimation is the $\mathrm{CO}_{2}$ produced in the process. The concentrate includes carbonate minerals such as $\mathrm{MgCO}_{3}$ and $\mathrm{CaCO}_{3}$, which produce $\mathrm{CO}_{2}$ when leached. Many unit processes also use oxygen and air feed, resulting in gaseous emissions as the undissolved gases are released. Sodium sulfite is used for the oxidation of $\mathrm{CN}^{-}$ ion in cyanidation or reduction of gold on silica in halogen leaching. This chemical produces excess $\mathrm{SO}_{2}$ gas; thus, minor $\mathrm{SO}_{2}$ emissions are possible.

Mining waters have strict environmental limitations of dissolved elements in the discharged solutions. Sulfate is one of the species found in mine waters and is particularly problematic when in the form of a highly soluble sodium sulfate, as sulfates in water bodies can increase the salinity.

The wastewaters produced during the pressure oxidation do not contain notable amounts of dissolved metallic impurities after neutralization. However, as stated before, the sulfate concentration of the pressure oxidation waters $(17.6 \mathrm{~g} / \mathrm{L})$ is higher than the European reference effluent value of $1000 \mathrm{mg} /$ L (Bowell 2004). The geographical mine locations as well as local regulations define the finally the annual amounts of acceptable sulfate disposal. As an example, the acceptable sulfate concentration in a Finnish gold plant has been over $8000 \mathrm{mg} / \mathrm{L}$ in discharge water in the past, which has been lowered to $2000 \mathrm{mg} / \mathrm{L}$ with addition of sulfate removal process. (Pöyry, 2016) Furthermore, due to $\mathrm{MgCO}_{3}$ dissolution, there are $\mathrm{Mg}^{2+}$ ions $(4.45 \mathrm{~g} / \mathrm{L})$ in the water, which can form a common contaminant, $\mathrm{MgSO}_{4}$, which effect on aquatic toxicity has been studied by van Dam et al. (2010).

The wastewaters from the cyanidation process originate from detoxification processes. In the leaching simulation, the main concern of the wastewaters is the As concentration $(0.31 \mathrm{~g} / \mathrm{L})$. This is the amount of arsenic that is not precipitated in the pressure oxidation process. The As is predicted to be in As (III) form, which has high toxicity. Prior to releasing these waters into nature, the As (III) concentration needs to be lowered to acceptable safe levels of As(III), which in fresh water are $150 \mu \mathrm{g} / \mathrm{L}$ (chronic) and $340 \mu \mathrm{g} / \mathrm{L}$ (acute) (US EPA 2019). Similarly to wastewaters from pressure oxidation, also the waters from cyanidation have a high sulfate concentration $(49.7 \mathrm{~g} / \mathrm{L})$ and alkaline $\mathrm{pH}$ around 8.9 , precipitating, e.g., any dissolved $\mathrm{Fe}$ as hydroxides. In addition, the elution waters from gold recovery dilute the cyanide process water, and the impurities adsorbed by activated carbon are cleaned with hydrochloric acid. Suitable processing is needed for these waters prior to disposing them. The cyanide destruction (DETOX) is conducted after leaching, and success of this operation is critical in order to prevent $\mathrm{CN}^{-}$ions release to the nature, severe consequences are evident for the aquatic life in case of cyanide leakage.

For halogen leaching process the same sulfate issue remains, as the sulfate concentration in brine solution is $58.27 \mathrm{~g} / \mathrm{L}$. However, in halogen process, the aim is to produce a brine that can be circulated back to the process. Thus, also the iron $(0.71 \mathrm{~g} / \mathrm{L})$ and chloride $(70 \mathrm{~g} / \mathrm{L})$ concentrations are high. In addition, the brine is acidic. If some of these waters are not circulated for chloride recycling, the process solutions are required to be subjected to the state-of-art metal precipitation (e.g., as sulfides) and neutralization.

\subsubsection{Sensitivity analysis}

The results of any LCA study are particularly dependent on the inventory data used and the assumptions made in the study (Norgate and Haque 2012). In this study, the LCA inventory was produced based on the best available data gathered from published sources for simulation of gold processes to produce a mass balance. The electricity consumption was calculated based on the HSC Sim mass balance and known values from the literature. The equations and constants used in the electricity calculations are presented in the ESM S1.4.

A sensitivity analysis was conducted on the benchmark scenario by varying the consumption of electricity and water by 10 to $20 \%$. Variation of electricity consumption has a higher effect in halide leaching than in cyanidation in all impact categories. \pm 10 to $20 \%$ variation in electricity causes \pm 2.5 to $\pm 5.1 \%$ effect on GWP in halide leaching and \pm 2 to $\pm 4 \%$ variation in cyanidation. The pressure oxidation contributes more on the overall variation value, due to the higher volume of the unit process compared to leaching and recovery stages. Similarly, the sensitivity to AP and EP varies from \pm 4.8 to $\pm 7.1 \%$ and \pm 3.6 to $9.6 \%$ in halide leaching and $\pm 4.5 \%$ to $\pm 9.1 \%$ and \pm 3.8 to $\pm 7.5 \%$ in cyanidation.

By varying the water consumption in the processes, the sensitivity on estimated impacts is lower. In the cyanidation, \pm 10 to $20 \%$ variation leads to \pm 0.7 to $\pm 1.4 \%$ change in GWP, \pm 1.25 to 
$\pm 2.5 \%$ in $\mathrm{AP}, \pm 2.6$ to $\pm 5.1 \%$ in $\mathrm{EP}$, and \pm 0.9 to $\pm 1.8 \%$ in water depletion. For halide leaching, these variations are slightly larger; $\pm 0.74-1.5 \%$ (GWP), $\pm 1.1-3.95 \%$ (AP), $\pm 2-2.2 \%$ (EP), and $\pm 0.85-1.7 \%$ (water depletion). Similarly, in both processing routes, the pressure oxidation contributes more on sensitivities.

The effect of geographical location was investigated by comparing the effect the production region of electricity had on the process in high gold production countries, e.g., Australia and the USA. The electricity grid mix variation impacts all investigated environmental impact categories, Table 7 . The global warming potential increases from the benchmark Finland scenario for ca. $35-40 \%$ if the electricity is produced in Australia or China. In addition, when compared to Finnish base values, the acidification potential and eutrophication potential increase significantly. Both the Australian and Chinese electricity grid mix will increase the estimated AP or EP over $100 \%$. The electricity grid mix of USA has the largest impact on water depletion indicator with an increase of nearly $30 \%$.

\section{Discussion}

The challenge in the simulation was the limited amount of available industrial information about halogen leaching, as it is only at the development stage. Although there are several publications available on the halogen leaching of gold, most of them describe leaching on laboratory scale. Thus, the parameters used in halogen simulation may not be the optimized parameters for an industrial-scale process. The mass balance simulated in this study may predict higher water consumption and chemical consumption compared to what can be achieved on larger scale since (i) water from condensed steam is not recovered and (ii) leaching residue washing is not optimized for the halogen process. An evaporation step is simulated for the halogen leaching, which is not officially reported for the process in literature. Evaporation can be energy consuming, which is observed from the mass balance (Table 6).
However, electricity consumption to produce the required heating energy for this unit was not included in LCA estimations as the definition of equipment used for the unit process was uncertain. In addition, the estimated LCA would not describe the results for the simple published process, which initially did not include evaporation unit process. Additionally, the steady-state simulation does not take into account the retention times and reaction times of concentrate in leaching. As a result, it is hard to evaluate the benefit of fast kinetics in the halogen process compared to cyanidation, which can require leaching times of over $24 \mathrm{~h}$. This has an impact on the reactor sizes needed and thus the power consumption of the process, as significantly larger equipment is required. The reported leaching times for the halogen process can be as little as 1 to $2 \mathrm{~h}$.

The study was also limited by the LCA database used. The $\mathrm{NaCN}$ chemical and $\mathrm{Na}_{2} \mathrm{SO}_{3}$ chemicals were cutoff flows in the assessment as upstream process was not found in the database. The addition of $\mathrm{NaCN}$ to SCE1 environmental indicator estimations can increase the impact values of AP and EP of cyanidation.

However, the simulations built in this study can be modified according to specific requirements of existing processes to produce more accurate data. Thus, the life cycle assessment can also be improved according to increasing knowledge about the development stage processes. This unbiased study shows that, based on the literature, simulations of development-stage processes can be built and environmental indicators can be predicted. This is essential, since the emerging technologies should be assessed as early as possible for their environmental impact. There are still unresolved problems related to cyanide-free gold leaching concerning gold recovery and water balance. However, if these problems can be overcome, a more competitive alternative can be attained. In addition, this study has focused on evaluating the simulation and environmental indicators obtained, and a more comprehensive sustainability assessment could highlight even more differences between the scenarios in the light of costs and social impact.
Table 7 The effect of electricity grid mix locality to benchmark (Finland) values as percentage increase

\begin{tabular}{|c|c|c|c|c|c|c|c|c|}
\hline \multirow[t]{2}{*}{ Country } & \multicolumn{2}{|c|}{ GWP, $\mathrm{CO}_{2}-\mathrm{e}$} & \multicolumn{2}{|c|}{$\mathrm{AP}, \mathrm{H}^{+}$mole e. } & \multicolumn{2}{|c|}{ EP, $\mathrm{N}$ mole e. } & \multicolumn{2}{|c|}{$\begin{array}{l}\text { Water depletion, } \\
\mathrm{kg}\end{array}$} \\
\hline & SCE1 & SCE2 & SCE1 & SCE2 & SCE1 & SCE2 & SCE1 & SCE2 \\
\hline $\begin{array}{l}\text { Finland (benchmark } \\
\text { values) }\end{array}$ & 9.3 & 11.1 & 10.9 & 16.1 & 26.6 & 46.6 & 60.6 & 76.7 \\
\hline Australia & $35.3 \%$ & $38.7 \%$ & $150.8 \%$ & $111.6 \%$ & $170.6 \%$ & $151.6 \%$ & $3.1 \%$ & $2.9 \%$ \\
\hline USA & $18.2 \%$ & $21.6 \%$ & $11.5 \%$ & $8.6 \%$ & $55.0 \%$ & $50.9 \%$ & $26.7 \%$ & $29.2 \%$ \\
\hline China & $35.3 \%$ & $40.5 \%$ & $109.2 \%$ & $84.8 \%$ & $162.4 \%$ & $150.9 \%$ & $20.3 \%$ & $22.2 \%$ \\
\hline
\end{tabular}




\section{Conclusions}

The current study presents refractory gold concentrate pressure oxidation and two different leaching process simulations: state-of-art cyanidation (SCE1) and cyanide-free halogen process (SCE2), still at the development stage. Cyanidation simulation predicted $98.5 \%$ gold recovery, whereas the halide leaching indicated a final gold recovery of only $87.3 \%$, due to gold lost in the leach residue and wash waters along with the remaining cake moisture. However, with the addition of a secondary gold recovery unit for the leach residue wash water (SCE2b), gold recovery could be increased in halide leaching up to $98.5 \%$. The halogen simulation predicted the consumption of $5 \mathrm{~kg} \mathrm{NaBr}$ and $140 \mathrm{~kg} \mathrm{NaCl}$ per ton of concentrate. The brine from evaporation could be used to lower the consumption of fresh chloride chemicals. The acidification and eutrophication potential have significant impact through $\mathrm{NaCl}$ production, which can be minimized with efficient recycling of the chloride chemicals.

The estimated environmental impacts predict that the development-stage cyanide-free process still has some challenges compared to cyanidation, as in the investigated scenarios the environmental impacts were generally higher for halogen leaching. This is mostly due to the lower recovery of gold (SCE2) in the process, as the environmental indicators are estimated based on the functional unit of $1 \mathrm{~kg}$ of Au. The simultaneous leaching and recovery on the activated carbon in carbonin-leach process (SCE1) prevents gold losses to the leach residue and wash waters, since it uses a reagent $(\mathrm{NaCN})$ that can be decomposed chemically (detoxification). The investigated halide leaching (SCE2) was based on separate leaching and recovery units, which results in gold losses to the moisture of the leach residue and wash waters. The washing of chlorides out of the leach residue further challenges the process water balance, leading to water accumulation. In the current study, the global warming potential of refractory gold concentrate treatment by POX and cyanidation was $10.3 \mathrm{t} \mathrm{CO}_{2}$-e/ $\mathrm{kg} \mathrm{Au}$, whereas POX followed by halogen leaching resulted in a $22 \%$ higher GWP, $12.6 \mathrm{t} \mathrm{CO}_{2}$-e/kg Au. However, if the issues regarding gold recovery can be overcome in the halide process (SCE2b), a more competitive alternative will be obtained, lowering the GWP to $11.5 \mathrm{t} \mathrm{CO}_{2}$-e/kg Au. Further process improvements, for example in the form of decreased moisture in the feed for halide leaching, and the adaptation of in situ gold recovery practices in chloride leaching as well, may give the cyanidefree processing options a competitive edge.

Acknowledgments Open access funding provided by Aalto University. Arif Aji, M.Sc.; Pyry Hannula, D.Sc.; and Maria Leikola, M.Sc. are greatly acknowledged for valuable comments and discussions. Erno Laakso B.Sc. (Architechture) is thanked for help with visualizations.

Funding information The authors would like to thank the Emil Aaltonen Foundation for its financial support of the Sustainable gold project. This research is supported by Finnish Foundation for Technology Promotion. In addition, GoldTail (grant nr 319691), funded by the Academy of Finland, is gratefully acknowledged.

Open Access This article is licensed under a Creative Commons Attribution 4.0 International License, which permits use, sharing, adaptation, distribution and reproduction in any medium or format, as long as you give appropriate credit to the original author(s) and the source, provide a link to the Creative Commons licence, and indicate if changes were made. The images or other third party material in this article are included in the article's Creative Commons licence, unless indicated otherwise in a credit line to the material. If material is not included in the article's Creative Commons licence and your intended use is not permitted by statutory regulation or exceeds the permitted use, you will need to obtain permission directly from the copyright holder. To view a copy of this licence, visit http://creativecommons.org/licenses/by/4.0/.

\section{References}

Aylmore MG (2016) Alternative lixiviants to cyanide for leaching gold ores. Gold ore processing (Second Edition). Elsevier pp 447-484

Aylmore MG, Muir DM (2001) Thiosulfate leaching of gold-a review. Miner Eng 14(2): 135-174

Baghalha M (2007) Leaching of an oxide gold ore with chloride/ hypochlorite solutions. Int J Miner Process 82(4):178-186

Bashtan SY, Goncharuk VV, Chebotareva RD, Belyakov VN, Linkov VM (1999) Production of sodium hypochlorite in an electrolyser equipped with a ceramic membrane. Desalination 126(1-3):77-82

Bowell RJ (2004) A review of sulfate removal options for mine waters. In: Jarvis AP, Dudgeon BA, Younger PL (eds) Proceedings of mine water 2004 - process, policy and progress. Newcastle University, Newcastle, pp 75-88

Brierley JA, Brierley CL (2001) Present and future commercial applications of biohydrometallurgy. Hydrometallurgy 59(2-3):233-239

Childers HEI, Matousek RC, Falcon L (2007) Process for producing hypochlorite. U.S. patent no 11/176,848. p 9

Conway MH, Gale DC (1990) Sulfur's impact on the size of pressure oxidation autoclaves. JOM J Miner Met Mater Soc 42(9):19-22

De Michelis I, Olivieri A, Ubaldini S, Ferella F, Beolchini F, Vegliò F (2013) Roasting and chlorine leaching of gold-bearing refractory concentrate: experimental and process analysis. Int J Min Sci Technol 23(5):709-715

Elsner L (1846) Beobachtungen über das Verhalten regulinischer Metalle in einer wässrigen Lösung von Cyankalium. J Prakt Chem 37(1):441-446

Fleming CA (1992) Hydrometallurgy of precious metals recovery. Hydrometallurgy 30(1-3):127-162

Fleming C, Geldart J, Blatter P, Cousin P, Robitaille J, Young CA, Taylor PR, Anderson CG, Choi Y (2008) Flowsheet development for Agnico Eagle's refractory gold Kittila project in Finland. In: Young CA, Taylor PR, Anderson CG, Choi Y (2008). Hydrometallurgy 2008 Proceedings of the Sixth International Symposium. Society for Mining, Metallurgy, and Exploration (SME). Retrieved from https:// app.knovel.com/hotlink/toc/id:kpHPSIS00R/hydrometallurgy-2008/ hydrometallurgy-2008

Fraser KS, Walton RH, Wells JA (1991) Processing of refractory gold ores. Miner Eng 4(7-11):1029-1041

Ghodrat M, Rhamdhani MA, Brooks G, Rashidi M, Samali B (2017) A thermodynamic-based life cycle assessment of precious metal recycling out of waste printed circuit board through secondary copper smelting. Environ Dev 24:36-49

Haavanlammi L, Hyvärinen O, Tiihonen M, Tontti R (2010) Method for recovering gold. U.S. Patent No 7,799,114. p 6 
Hammerschmidt J, Güntner J, Kerstiens B, Charitos A (2016) Roasting of gold ore in the circulating fluidized-bed technology. Gold ore processing (Second Edition). Elsevier Amsterdam, pp 393-409

Haque KE (1987) Gold leaching from refractory ores-literature survey. Min Proc Ext Met Rev 2(3):235-253

Harris B, White C (2014) Process for the recovery of gold from an ore in chloride medium with a nitrogen species. US Patent No 8,894,740. p 11

Hayes PC (1985) Process selection in extractive metallurgy. Hayes Publishing Co, Brisbane ISBN 0-9589197-0-4

Hilson G, Monhemius AJ (2006) Alternatives to cyanide in the gold mining industry: what prospects for the future? J Clean Prod 14(12-13):1158-1167

Iglesias N, Carranza F (1994) Refractory gold-bearing ores: a review of treatment methods and recent advances in biotechnological techniques. Hydrometallurgy 34(3):383-395

Ishiguro Y, Hosaka H, Ylshimura A, Takabayashi K, Abe Y (2008) Process of leaching gold. AU Patent, 202814, B8

ISO 14040 (2006) Environmental management, life cycle assessment, principles and framework. Finnish Standards Association SFS, Helsinki, p 49

ISO 14044 (2006) Environmental management, life cycle assessment, requirements and guidelines. Finnish Standards Association SFS, Helsinki, p 96

Jaatinen T (2011) Bio-oxidation and bioleaching of arsenic-containing and refractory gold concentrates. Master's Thesis. Tampere University of Technology, Tampere

Jeffrey MI, Breuer PL, Choo WL (2001) A kinetic study that compares the leaching of gold in the cyanide, thiosulfate, and chloride systems. Metall Mater Trans B Process Metall Mater Process Sci 32(6):979-986

Kianinia Y, Khalesi MR, Abdollahy M, Hefter G, Senanayake G, Hnedkovsky L, Khodadadi Darban A, Shahbazi M (2018) Predicting cyanide consumption in gold leaching: a kinetic and thermodynamic modeling approach. Minerals 8(3):110, $13 \mathrm{p}$

Kotiranta T, Horn S, Jansson K, Reuter MA (2015) Towards a "minimum impact" copper concentrator: a sustainability assessment. Procemin Symposium, $15^{\text {th }}$ International Minerals Processing Conference, October 21J-23, Santiago, Chile

Kuhn AT, Lartey RB (1975) Electrolytic generation "in-situ" of sodium hypochlorite. Chem Ing Tech 47(4):129-135

La Brooy SR, Linge HG, Walker GS (1994) Review of gold extraction from ores. Miner Eng 7(10):1213-1241

Lalancette J (2009) Gold and silver recovery from polymetallic sulfides by treatment with halogens. U.S. Patent No 7,537,741. p 13

Lalancette J, Dubreuil B, Lemieux D (2015a) Closed loop method for gold and silver extraction by halogens. U.S. Patent No 9,206,492. p 7

Lalancette J, Dubreuil B, Lemieux D (2015b) Method and system for gold recovery. U.S. Patent No 9,206,491. p 4

Lampinen M, Seisko S, Forsström O, Laari A, Aromaa J, Lundström M, Koiranen T (2017) Mechanism and kinetics of gold leaching by cupric chloride. Hydrometallurgy 169:103-111

Lemieux D, Lalancette JM, Dubreuil B (2014) Treatment of a gold refractory concentrate with halogens. In: Asselin E, Dixon DG, Doyle FM, Dresinger DB, Jeffrey MI, Moats MS (eds) Proceedings of the 7th International Symposium on Hydrometallurgy 2014. June 2225, 2014, Victoria, British Columbia, Canada, vol. 1. Canadian Institute of Mining, Metallurgy \& Petroleum, Montreal, pp 581-589

Llamas AA, Delgado AV, Capilla AV, Cuadra CT, Hultgren M, Peltomäki M, Roine A, Stelter M, Reuter MA (2019) Simulation-based exergy, thermo-economic and environmental footprint analysis of primary copper production. Miner Eng 131:51-65

Lundström M, Ahtiainen R, Haakana T, O'Callaghan J (2014) Technoeconomical observations related to Outotec gold chloride process. In: Proceedings of ALTA 2014, 24-31 May, Perth, pp 89-104

Lundström M, Ahtiainen R, Laihonen P, Lindgren M (2015) Possibilities and challenges in gold chloride processing. In: Proceedings of ALTA 2015, 22-30 May, Perth, pp 269-280
Marchbank AG, Thomas KG, Dreisinger D, Fleming C (1996) Gold recovery from refractory carbonaceous ores by pressure oxidation and thiosulfate leaching. U.S. Patent No 5,536,297. p 17

Marsden J, House I (2006) The chemistry of gold extraction. SME

Mason PG, Wicks FD, Gathje JC (1985) Process for the recovery of gold from refractory ores by pressure oxidation. U.S. Patent No 4,552,589. p 10

Mular AL, Halbe DN, Barratt DJ (2002) Mineral processing plant design, practice, and control: proceedings. SME

Multani RS Feldmann T, Demopoulos GP (2016) Antimony in the metallurgical industry: a review of its chemistry and environmental stabilization options. Hydrometallurgy 164:141-153

Nicol MJ, Fleming CA, Paul RL (1987) The chemistry of the extraction of gold. In: Stanley GC (ed) The extraction metallurgy of gold in South Africa. South African Institute of Mining and Metallurgy, Johannesburg, pp 831-905

Norgate T, Haque N (2012) Using life cycle assessment to evaluate some environmental impacts of gold production. J Clean Prod 29:53-63

Norgate T, Jahanshahi S (2010) Low grade ores-smelt, leach or concentrate? Miner Eng 23(2):65-73

Norgate TE, Jahanshahi S, Rankin WJ (2007) Assessing the environmental impact of metal production processes. J Clean Prod 15(8-9):838-848

Outotec (2018) HSC Chemistry 9.4.1. https://www.outotec.com/ products/digital-solutions/hsc-chemistry/

Pangum LS, Browner RE (1996) Pressure chloride leaching of a refractory gold ore. Miner Eng 9(5):547-556

Pöyry (2015) Rikastamon syötemäärän sekä rikastushiekan varastointikapasiteetin kasvattaminen Kittilän kultakaivoksella. Ympäristövaikutusten arviointiohjelma. Available at: https://www. ymparisto.fi/fi-FI/Asiointi_luvat_ja_ymparistovaikutusten arviointi/Ymparistovaikutusten_arviointi/YVAhankkeet/ Suurikuusikon_kaivoksen tuotanto_ja_varastointimaaran kasvattaminen/Suurikuusikon_kaivoksen_tuotanto_ja_vara (33199). Accessed 12.4.2019

Pöyry, 2016. Rikastamon syötemäärän sekä NP rikastushiekan varastointikapasiteetin kasvattaminen Kittilän kultakaivoksella. Agnico Eagle Finland Oy. Environmental impact assessment, EIA. Availabe at: https://www.ymparisto.fi/fi-FI/Asiointi_luvat_ja ymparistovaikutusten_arviointi/Ymparistovaikutusten_arviointi/ YVAhankkeet/Suurikuusikon kaivoksen tuotanto ja varastointimaaran_kasvattaminen Accessed 29 Nov 2019

Reuter MA, Van Schaik A, Gediga J (2015) Simulation-based design for resource efficiency of metal production and recycling systems: cases-copper production and recycling, e-waste (LED lamps) and nickel pig iron. Int J Life Cycle Assess 20(5):671-693

Rose TK (1898) The metallurgy of gold. C. Griffin, Ltd

Seisko S, Lampinen M, Aromaa J, Laari A, Koiranen T, Lundström M (2018) Kinetics and mechanisms of gold dissolution by ferric chloride leaching. Miner Eng 115:131-141

Swash PM, Monhemius AJ (1998) The scorodite process: a technology for the disposal of arsenic in $21^{\text {st }}$ century. Effluent treatment in the Mining Industry. University of Concepción, Concepción, p 389

thinkstep (2019) GaBi software-system and database for life cycle engineering. Copyright 1992-2016 thinkstep AG

Thomas KG, Pieterse HJ, Brewer RE, Fraser KS (1990) Process for recovery of gold from refractory ores. U.S. Patent No 5,071,477. p 18

Tran T, Lee K, Fernando K (2001) Halide as an alternative lixiviant for gold processing- an update, cyanide: social, industrial and economic aspects as held at the 2001 TMS Annual Meeting 2001, pp 501-508

US EPA (2019) National Recommended Water Quality Criteria. Available: https://www.epa.gov/wqc/national-recommended-waterquality-criteria-aquatic-life-criteria-table. Accessed: 3.10.2019

Van Dam RA, Hogan AC, McCullough CD, Houston MA, Humphrey CL, Harford AJ (2010) Aquatic toxicity of magnesium sulfate, and the influence of calcium, in very low ionic concentration water. Environ Toxicol Chem 29(2):410-421 
Wahlström M, Laine-Ylijoki J, Vestola E, Vaajasaari K, Joutti A (2006) Jätteiden kaatopaikkakelpoisuuden toteaminen. Ympäristöhallinön ohjeita 2. Ympäristöministeriö, Ympäristönsuojeluosasto. Edita Prima Oy, Helsinki. ISBN 952-11-2335-4 (PDF)

Yen WT, Pindred RA, Lam MP (1990) Hypochlorite leaching of gold ore. Hydrometallurgy fundamentals, technology and innovations, the Society for Mining. Metallurgy and Exploration, Inc., Littleton, pp 415-436
Zhang Y, Fang Z, Muhammed M (1997) On the solution chemistry of cyanidation of gold and silver bearing sulphide ores. A critical evaluation of thermodynamic calculations. Hydrometallurgy 46(3):251-269

Publisher's note Springer Nature remains neutral with regard to jurisdictional claims in published maps and institutional affiliations. 